\title{
50. MAGNETOSTRATIGRAPHIC AND BIOSTRATIGRAPHIC SYNTHESIS OF OCEAN DRILLING PROGRAM LEG 105: LABRADOR SEA AND BAFFIN BAY ${ }^{1}$
}

\author{
Jack G. Baldauf, ${ }^{2}$ Bradford Clement, ${ }^{2,3}$ Ali E. Aksu, ${ }^{4}$ Anne de Vernal, ${ }^{5}$ John Firth, ${ }^{6}$ Frank Hall, ${ }^{7}$ Martin J. Head, ${ }^{8}$ \\ Richard Jarrard, ${ }^{9}$ Michael A. Kaminski, ${ }^{10}$ Dave Lazarus, ${ }^{11}$ Anne-Lise Monjanel, ${ }^{12}$ William A. Berggren, ${ }^{10}$ \\ Felix Gradstein, ${ }^{13}$ Stephen Knuttel, ${ }^{6}$ Peta Mudie, ${ }^{13}$ and Merlin D. Russell, Jr. ${ }^{6}$
}

\begin{abstract}
During Ocean Drilling Program (ODP) Leg 105, three sites (Sites 645 through 647) were drilled in Baffin Bay and the Labrador Sea to examine the tectonic evolution and the climatic and oceanic histories of this region. Biostratigraphic and magnetostratigraphic results vary at each site, while stratigraphic resolution depends on the limited abundance of marker species and the completeness of the paleomagnetic record. Because of the paucity of planktonic microfossils and the poor paleomagnetic record signatures, stratigraphic determinations at Site 645 often rely on defining minimum temporal constraints on specific samples or stratigraphic intervals. The completed stratigraphy indicates that the sedimentary sequence recovered at Site 645 is early Miocene to Holocene in age.

The magnetostratigraphy and biostratigraphies are better defined at Sites 646 and 647 in the Labrador Sea. Site 646 generally contains a well-developed magnetostratigraphy and calcareous microfossil biostratigraphy. This biostratigraphy is based on calcareous nannofossils and planktonic foraminifers typical of the North Atlantic Ocean. Siliceous microfossils are also present at Site 646, but they are restricted to upper Pliocene through Holocene sediments. The stratigraphic sequence recovered at Site 646 is late Miocene to Holocene in age.

Based primarily on the calcareous nannofossil stratigraphy, the sequence recovered at Site 647 consists of lower Eocene to lower Oligocene, lower Miocene, upper Miocene, and upper Pliocene through Holocene sediments. Three hiatuses are present in this sequence: the older hiatus separates lower Oligocene sediments from lower Miocene sediments, another hiatus separates lower Miocene sediments from upper Miocene sediments, and the youngest one separates upper Miocene from upper Pliocene sediments. A magnetostratigraphy is defined for the interval from the Gauss/Matuyama boundary through the Brunhes (Clement et al., this volume). Both planktonic foraminifers and siliceous microfossils have restricted occurrences. Planktonic foraminifers occur in Pliocene and younger sediments, and siliceous microfossils are present in lower Miocene and lower Oligocene sediments.

The near-continuous Eocene through lower Oligocene sequence recovered at Site 647 allows the calcareous nannofossils and diatom stratigraphies at this site to act as a Paleogene stratigraphic framework. This framework can be compared with the stratigraphy previously completed for DSDP Site 112.
\end{abstract}

\section{INTRODUCTION}

ODP Leg 105 allowed us a unique opportunity to examine high-latitude microfossil faunas and floras and to compare these with the faunas and floras in the middle and low latitudes. Besides Leg 105, Deep Sea Drilling Project (DSDP) Leg 12 (Laughton, Berggren, et al., 1972) is the only other DSDP or ODP

\footnotetext{
${ }^{1}$ Srivastava, S. P., Arthur, M., Clement, B., et al., 1989. Proc. ODP, Sci. Results, 105: College Station, TX (Ocean Drilling Program).

2 Ocean Drilling Program, Texas A\&M University, College Station, TX 77843.

3 Department of Geology, Florida International University, University Park, Tamiami Trail, Miami, FL 33199.

${ }^{4}$ Department of Earth Sciences, Memorial University of Newfoundland, St. John's, Newfoundland AIB 3X5, Canada.

5 GEOTOP, Université du Quebec a Montreal, C.P. 8888, Succ. A, Montreal, Quebec H3C 3P8, Canada.

6 Department of Geology, Florida State University, Tallahassee, FL 32306.

7 Graduate School of Oceanography, University of Rhode Island, Narragansett Bay Campus, Narragansett, RI 02882.

8 Department of Geology, University of Toronto, 170 College Street, Toronto, Ontario M5S 1A1, Canada.

${ }^{9}$ Lamont-Doherty Geological Observatory, Columbia University, Palisades, NY 10964.

10 WHOI/MIT Joint Program in Oceanography, Woods Hole Oceanographic Institution, Woods Hole, MA 02443. Currently at Centre for Marine Geology, Dalhousie University, Halifax, Nova Scotia B3H 3J5, Canada.

11 Department of Geology and Geophysics, Woods Hole Oceanographic Institution, Woods Hole, MA 02443.

${ }^{12}$ Université de Bretagne Occidentale, Gis “Océanologie et Géodynamique," 6 Avenue le Gorgeu, 19187 Brest Cedex, France.

13 Atlantic Geoscience Center, Geological Survey of Canada, Box 1006, Dartmouth, Nova Scotia B2Y 4A2, Canada.
}

cruise to recover sediments from the Labrador Sea region. Leg 105 is the first DSDP or ODP cruise to recover sediments from Baffin Bay. Here, we summarize magnetostratigraphic and biostratigraphic results from Leg 105 drilling.

Eleven holes were cored at three sites (645 through 647) during Leg 105 (Table 1, Fig. 1). The lower Miocene to Holocene sediments recovered from Baffin Bay Site 645 contain a large
Table 1. Latitude, longitude, and water depth (sea-level corrected, echo-soundings) of holes drilled during Leg 105.

\begin{tabular}{lccc}
\hline & Latitude & Longitude & $\begin{array}{c}\text { Water } \\
\text { depth (m) }\end{array}$ \\
\hline Site 645 & & & \\
Hole 645A & $70^{\circ} 27.43^{\prime} \mathrm{N}$ & $64^{\circ} 39.26^{\prime} \mathrm{W}$ & 2005.8 \\
Hole 645B & $70^{\circ} 27.43^{\prime} \mathrm{N}$ & $64^{\circ} 39.26^{\prime} \mathrm{W}$ & 2001 \\
Hole 645C & $70^{\circ} 27.43^{\prime} \mathrm{N}$ & $64^{\circ} 39.26^{\prime} \mathrm{W}$ & 2001 \\
Hole 645D & $70^{\circ} 27.43^{\prime} \mathrm{N}$ & $64^{\circ} 39.37^{\prime} \mathrm{W}$ & 2005.8 \\
Hole 645E & $70^{\circ} 27.48^{\prime} \mathrm{N}$ & $64^{\circ} 39.30^{\prime} \mathrm{W}$ & 2005.8 \\
Hole 645F & $70^{\circ} 27.48^{\prime} \mathrm{N}$ & $64^{\circ} 39.29^{\prime} \mathrm{W}$ & 2005.8 \\
Hole 645G & $70^{\circ} 27.48^{\prime} \mathrm{N}$ & $64^{\circ} 39.29^{\prime} \mathrm{W}$ & 2005.8 \\
Site 646 & & & \\
Hole 646A & $58^{\circ} 12.56^{\prime} \mathrm{N}$ & $48^{\circ} 22.15^{\prime} \mathrm{W}$ & 3450.8 \\
Hole 646B & $58^{\circ} 12.56^{\prime} \mathrm{N}$ & $48^{\circ} 22.15^{\prime} \mathrm{W}$ & 3450.8 \\
Site 647 & & & \\
Hole 647A & $53^{\circ} 19.88^{\prime} \mathrm{N}$ & $45^{\circ} 15.72^{\prime} \mathrm{W}$ & 3861.8 \\
Hole 647B & $53^{\circ} 19.88^{\prime} \mathrm{N}$ & $45^{\circ} 15.72^{\prime} \mathrm{W}$ & 3861.8 \\
\hline
\end{tabular}




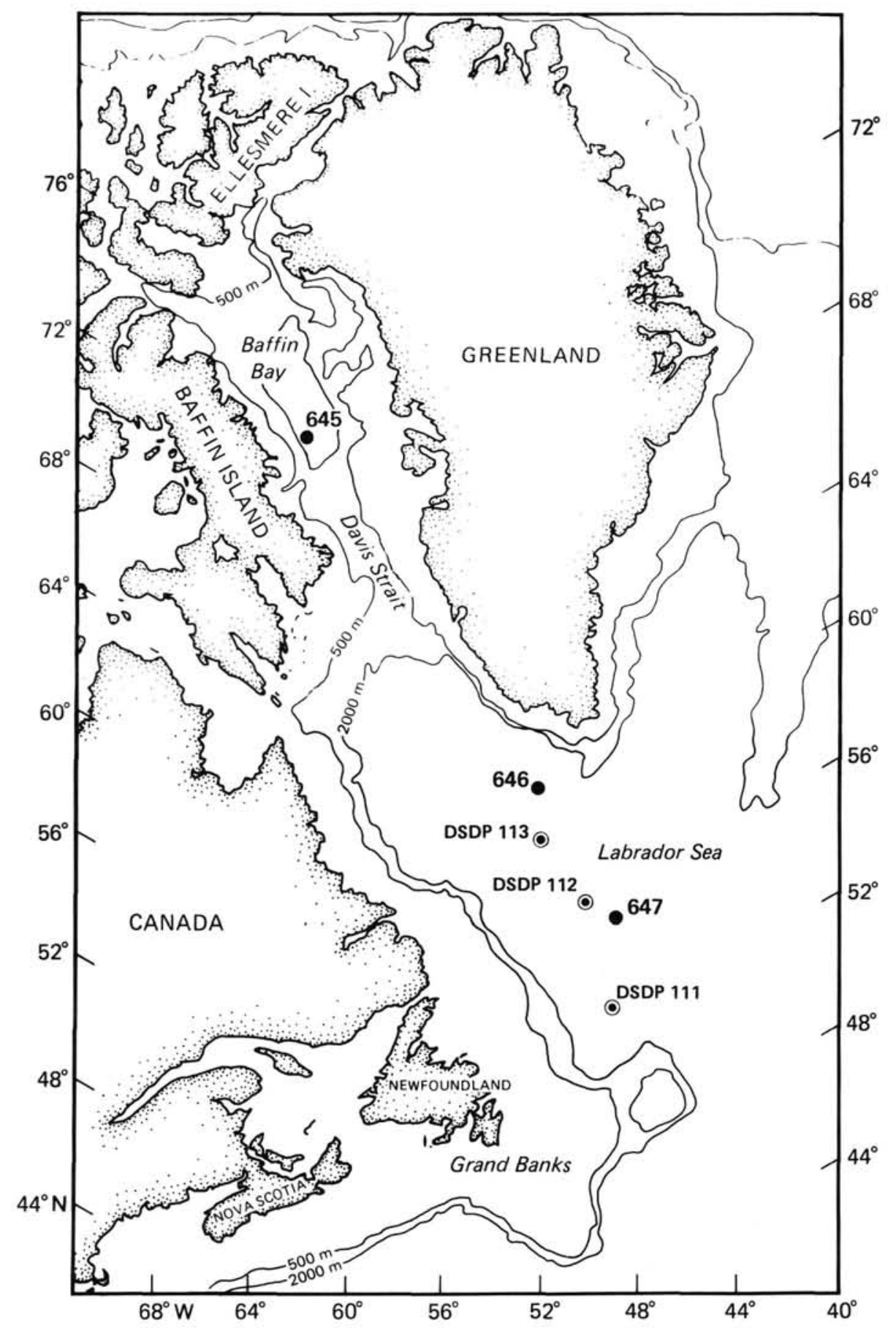

Figure 1. Location of sites drilled during ODP Leg 105 and DSDP Leg 112.

terrigenous component with sparse planktonic microfossils. The paucity of microfossils limits the chronostratigraphic control at this site and also limits stratigraphic correlations between Baffin Bay and the middle latitudes of the North Atlantic.

Lower Eocene to Holocene sediments were recovered from the Labrador Sea (combined Sites 646 and 647). The abundant and diverse microfossils, in addition to a reliable magnetostratigraphy for the upper portion of the sequences, allowed us to complete well-defined stratigraphies at these sites. The Paleogene sequence recovered at Site 647 contains both siliceous and calcareous microfossils and, to date, includes one of the most complete lower Oligocene sequences ever recovered. Refined bio- stratigraphies at this site allowed us to reevaluate the biostratigraphies previously completed at DSDP Site 112 .

\section{CHRONOSTRATIGRAPHY}

We established a biostratigraphic framework for use during Leg 105 that is based on the chronostratigraphy of Berggren et al. (1985a, 1985b; Figs. 2 and 3). Both low-latitude microfossil zonations as well as zonal schemes established for the Norwegian-Greenland Sea and the high-latitude North Pacific are incorporated into this framework. We established this biostratigraphic framework only as a reference point to allow comparisons between the observed species and their stratigraphic ranges 
with a known chronostratigraphy. The microfossil zones and their calibration to the chronostratigraphy of Berggren et al. (1985a) are discussed next.

The calcareous nannofossil zonations of Martini (1971) and Martini and Müller (1986) are used when possible. However, these zonations are primarily based on low-latitudes species that are excluded in part from Leg 105 sites (Firth et al., this volume; Knuttel et al., this volume). Müller (1976) encountered similar difficulties in the Norwegian Sea region and, as a result, modified Martini's zonation (1971) by combining zones defined on warm-water species into broader intervals based on cold-water species. Two of the intervals defined by Müller (1976) also are recognized in the Leg 105 studies. Calibration of calcareous nannofossil events to the magnetic polarity time scale follows Berggren et al. (1985a). The intervals used by Müller (1976) are correlated with Martini's zonation and are indirectly calibrated to the magnetic polarity time scale.

The correlation of planktonic foraminifer datums and zones to the chronostratigraphy of Berggren et al. (1985a) and to the calcareous nannofossil zonation of Martini (1971) follows that of Berggren et al. (1981; Aksu and Kaminski, this volume). Foraminiferal " $M$ " zones proposed by Berggren et al. (1983) and "PL" zones defined by Berggren $(1972,1977)$ have limited use in Labrador Sea sediments, primarily because these zonations are based on tropical and subtropical species. The temperate zonal marker species of Weaver and Clement (1986) may be used in the Labrador Sea, but diachrony has been observed in some planktonic foraminiferal datums between the eastern and western North Atlantic. The polar and subpolar species that occur at Leg 105 sites are generally characterized by long stratigraphic ranges, limiting their stratigraphic use.

Diatom biostratigraphic studies during Leg 105 adhere, when possible, to the diatom zonations of Koizumi (1973) and Baldauf $(1984,1987)$. The Neogene zonation of Koizumi (1973), which was later refined by Barron (1980), was originally defined for use in the middle and high-latitude North Pacific Ocean. However, recent biostratigraphic studies showed that this zonation was applicable in the Norwegian-Greenland Sea (Dzinordize et al., 1978; Eldholm, Thiede, et al., 1987), the high latitude North Atlantic (Baldauf, 1984, 1987), and the Labrador Sea (Monjanel and Baldauf, this volume).

The middle Miocene through Holocene diatom zonation defined by Baldauf $(1984,1987)$ is based on warm-water diatom assemblages observed in sediments recovered from the middle and high-latitude North Atlantic Ocean. This zonation is only partially applicable for the Labrador Sea sites. Correlation of the Neogene diatom datums to the magnetostratigraphy is based on studies by Barron et al. (1986) and Baldauf (1984, 1985, and 1987).

Both Schrader and Fenner (1976) and Dzinordize et al. (1978) defined Paleogene diatom zones for the Norwegian Sea. These zonations are based on species endemic to the Norwegian Sea or on species that have an uncertain stratigraphic range. Additional Paleogene diatom zonations were defined by Gombos (1982) and Fenner (1985) for the low latitudes and high southern latitudes. Leg 105 Paleogene zonation is based on cosmopolitan species and incorporates parts of the previous zonations discussed above (Baldauf and Monjanel, this volume).

We used two different radiolarian zonations to date sediments from Baffin Bay and the Labrador Sea (Srivastava, Arthur, et al., 1987), although neither zonation is satisfactory, and many samples cannot be assigned an age. The standard low-latitude radiolarian zonation of Riedel and Sanfilippo (1978) is only partially applicable, as most of the zonal indicators are exclusively tropical-to-temperate species and are missing in highlatitude sediments. The radiolarian zonation is based on a highlatitude assemblage recovered from the Norwegian Sea during DSDP Leg 38 (Bjorkland, 1976) and ODP Leg 104 (Bjorkland and Goll, in press). Although many Leg 105 radiolarian species show affinities with other high-latitude assemblages from the North Pacific and Southern Ocean, most stratigraphically useful forms are absent.

Palynomorphs (dinocysts and pollen) also were examined during Leg 105 (de Vernal and Mudie, this volume; Head and Mudie, this volume; Head and Norris, this volume). Although this microfossil group could not be calibrated directly to the chronostratigraphy of Berggren et al. (1985a), this group was extremely useful during Leg 105 . This is especially true in Baffin Bay, where with the exception of the benthic foraminifers, palynomorphs were the only other microfossil group consistantly encountered. The palynomorph stratigraphy in part relies on the previous work of de Vernal et al. (1986), Mudie (1986, 1987), and Edwards (1984).

\section{SUMMARY OF PALEOMAGNETICS AND MICROFOSSILS}

\section{Magnetostratigraphy}

Intermittant recovery, drilling disturbance resulting from rotary coring techniques, and the severe weather conditions encountered during Leg 105 hampered the magnetostratigraphic study of sediments recovered from Sites 645, 646, and 647. In particular, incomplete recovery of undisturbed sediment and sparse biostratigraphic control make it difficult to correlate the polarity zones observed in sediments recovered at Site 645 in Baffin Bay with the geomagnetic polarity time scale. However, the relatively undisturbed, Pliocene-Pleistocene sediments recovered using the Advanced Piston Corer (APC) at Sites 646 and 647 yielded polarity sequences that can be readily correlated with the time scale. Deeper sequences cored using the Extended Core-Barrel (XCB) at Site 646 provide a coarse polarity sequence that, in light of the available biostratigraphic data, may be tentatively correlated with late Miocene reversal sequences (Chrons $\mathrm{C} 4 \mathrm{~N}$ through $\mathrm{C} 4 \mathrm{AN}$ ). The polarity records obtained from a relatively undisturbed upper Eocene sequence that was recovered from Hole 647A using the Rotary Core Barrel (RCB) can be correlated with Chronozones $\mathrm{C} 18$ through C19.

\section{Calcareous Nannofossils}

With the exception of a few scattered samples that contain lower Miocene and Miocene to lower Pliocene assemblages, calcareous nannofossils are generally absent from samples examined from Site 645. At both Sites 646 and 647, calcareous nannofossils are present and for the most part are well-preserved. However, occasional samples are barren of calcareous nannofossils. Site 646 contains an upper Miocene through Pleistocene sequence characterized by a subpolar assemblage and a warmer transitional (subpolar/subtropical) assemblage. These two assemblages alternate downcore, with the fluctuations best developed in the Pleistocene interval.

Calcareous nannofossils also are present throughout most of the sequence recovered at Site 647 and are the primary stratigraphic indicator at this site. The Paleogene sequence at Site 647 contains diverse, moderately to well-preserved, high-latitude nannofossil assemblages, with most of the Eocene and Oligocene zones of Martini (1971) recognized.

\section{Planktonic Foraminifers}

Samples were examined for planktonic foraminifers from all Leg 105 sites. With the exception of the uppermost $110.3 \mathrm{~m}$ of sediments and the sporadic and rare occurrence of poorly preserved specimens between 283.8 and 293.5 meters below seafloor (mbsf) and again at $1036.8 \mathrm{mbsf}$, samples examined from Site 645 are barren of planktonic foraminifers. The assemblage 


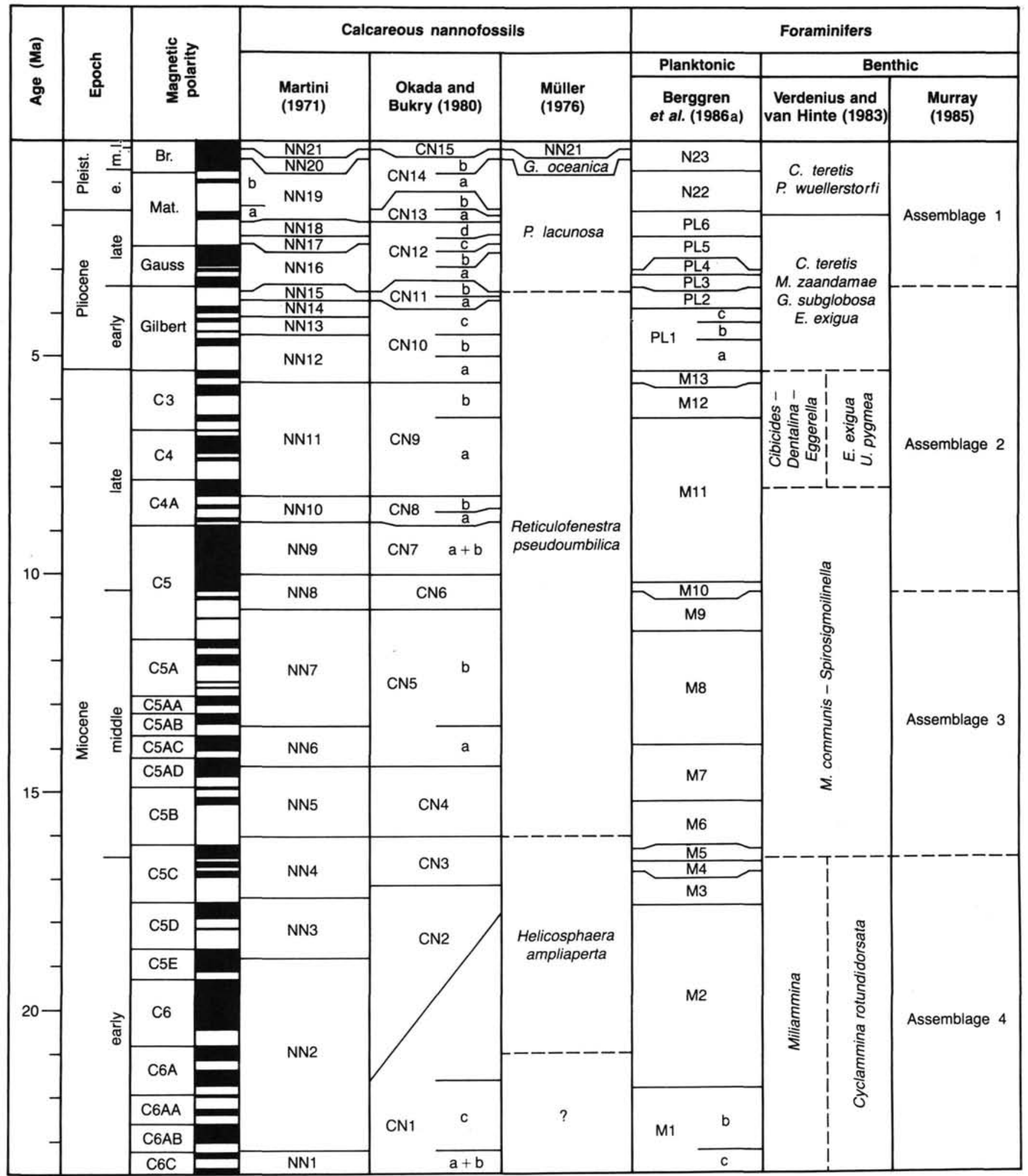

Figure 2. Correlation of the microfossil zones to the Neogene chronstratigraphy of Berggren et al., 1985a).

at this site is characterized by Neogloboquadrina pachyderma sinistral, with minor occurrences of $N$. pachyderma dextral, Globigerina quinqueloba, G. bulloides, and Globigerinita uvula.

Planktonic foraminifers are more abundant and exhibit better preservaton in the sedimentary sequences recovered from Sites 646 and 647. At Site 646, samples between 0 and 162.5 mbsf are characterized by a low diversity assemblage dominated by $N$. pachyderma sinistral and underlain by an assemblage dominated by $N$. atlantica below 188.2 mbsf. At Site 647, planktonic foraminifers are consistently present in Pliocene and Holocene sediments, but are rare from the Eocene-Oligocene and Miocene sequences. 


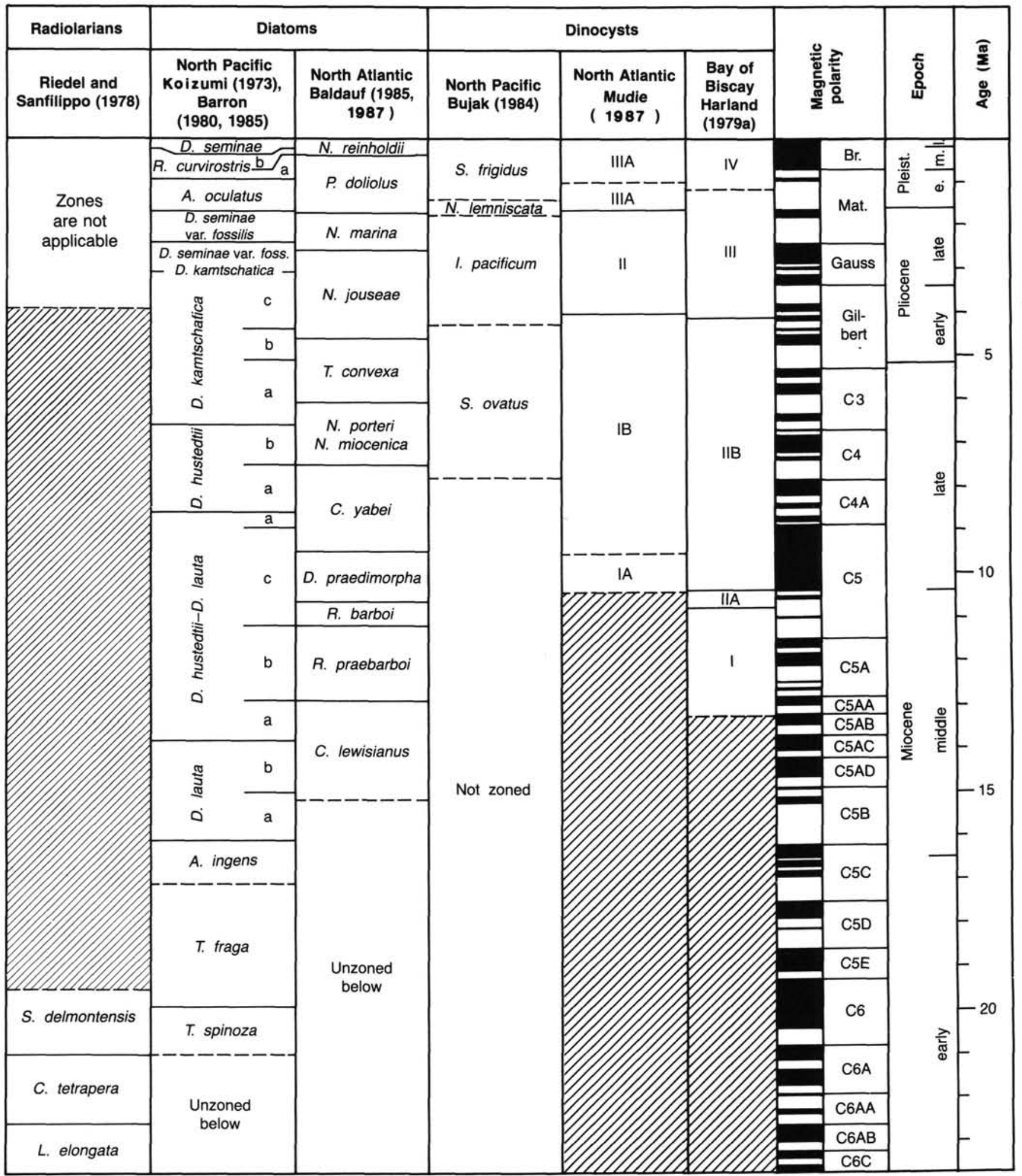

Figure 2 (continued).

\section{Diatoms}

In biosiliceous intervals, diatoms were examined from three to four samples of each core. One to two samples were routinely examined from each core in nonbiosiliceous intervals. Diatoms occur sporadically in lower Miocene to Holocene sediments re- covered at Site 645 and in upper Pliocene to Holocene sediments at Site 646. Diatoms are also present in Oligocene sediment recovered from Site 647, but are absent in Eocene and upper Miocene through Holocene sediments.

The diatom assemblage at Site 645 contains few stratigraphic indicators and consists primarily of fragmentated valves of spe- 


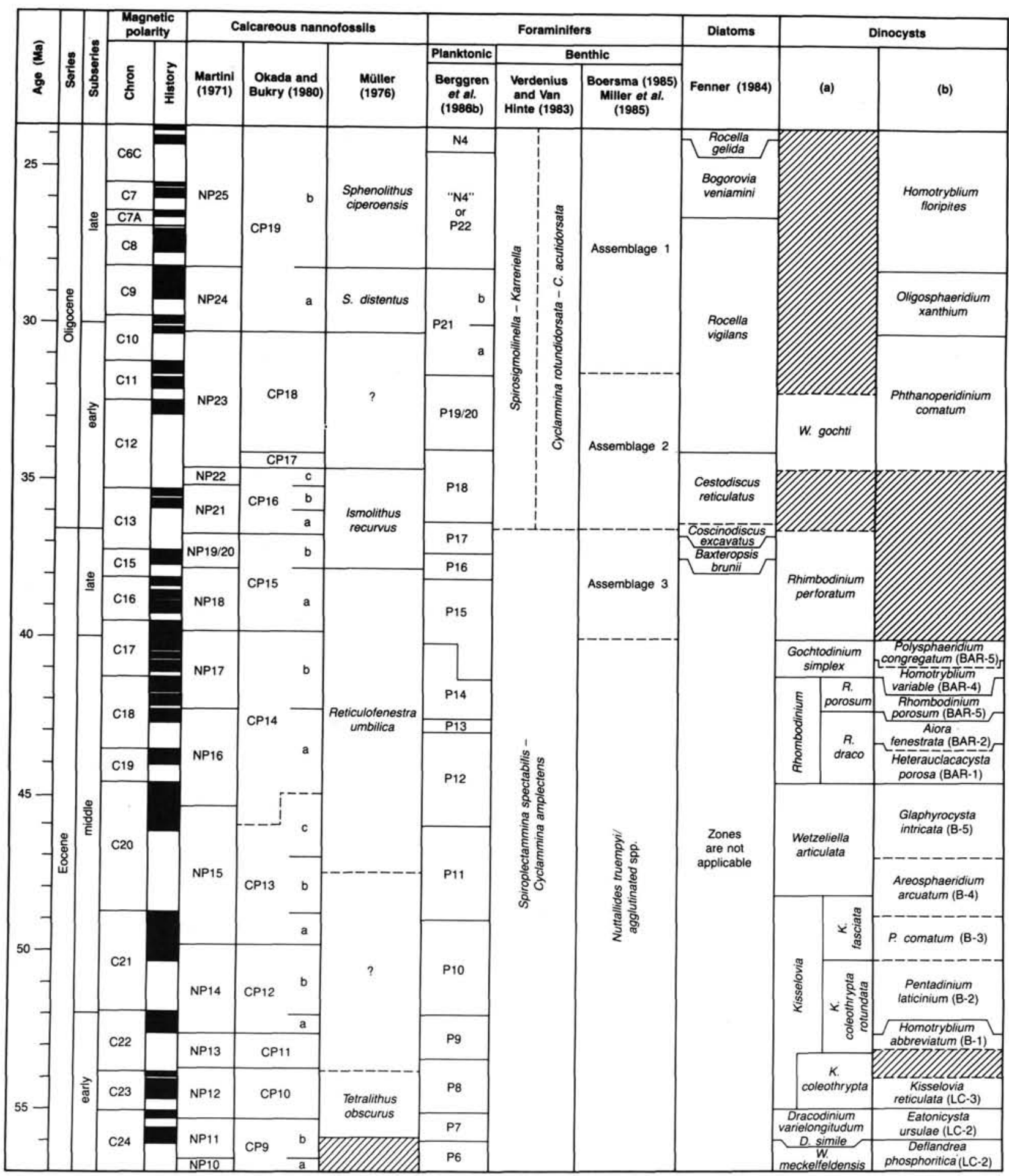

Figure 3. Correlation of the microfossil zones to the Paleogene chronstratigraphy of Berggren at al. (1985b). (a) = Costa and Downie (1976), Chateauneuf and Gruas-Cavagnelto (1978), and Bujak (1979). (b) = Eaton (1976), Bujak et al. (1980), and Benedek and Müller (1974).

cies characteristic of shelf and upper-slope environments. The diatom assemblage at Site 646 consists of species characteristic of high-latitude shelf and pelagic environments. The assemblage allows recognition of the diatom zonation defined for the North Pacific, but the ranges of primary and secondary bio- stratigraphic indicators are often unreliable because of their sporadic occurrences.

The Paleogene diatom assemblage present at Site 647 consists of species characteristic of the low latitudes, high southern latitudes, and the Norwegian-Greenland Sea. The Paleogene as- 
semblage is well preserved and diverse and allows the establishment of a composite stratigraphy that can be correlated with previously established diatom zones.

\section{Radiolarians}

Radiolarians generally are restricted to the same stratigraphic intervals as the other siliceous microfossils. They are absent from samples recovered at Site 645 and present only in the Pliocene and younger sequence at Site 646 and the lower Oligocene and lower Miocene sequences at Site 647. With the exception of lower Miocene sediments at Site 647, useful age estimates were generally not possible. Shore-based radiolarian studies emphasize documentation of the fauna, which contains many previously undescribed high-latitude species.

\section{Palynomorphs}

Palynomorphs were examined from core-catcher samples during Leg 105, while additional Neogene samples (generally one per core) were examined during shore-based studies. Palynomorphs are present in most Paleogene and Neogene samples examined; their abundance varies from sample to sample. The palynomorph assemblage contains marine (dinocysts and acritarchs), terrestrial (pollen and spores of Pteridophyata) and preNeogene reworked components. Palynomorph preservation varies from sample to sample, but is generally moderate at Site 645 and good at both Sites 646 and 647 . Reworked palynomorphs are present at all sites, but are most prevalent in the Paleogene sequence at Site 647.

Most of the observed palynomorph species have long stratigraphic ranges. However, several species, including $M$. minuta, $F$. filifera, $C$. hardlandii, and $N$. oblonga, were deemed stratigraphically useful for Leg 105 studies (see Srivastava, Arthur, et. al., 1987).

\section{SITE 645}

Site 645 lies on the continental slope off southern Baffin Island in a water depth of $2005.8 \mathrm{~m}$ (Table 1, Fig. 1). The coring record, biostratigraphic age constraints, and age determinations are correlated in Figure 4. Seven holes were drilled at Site 645 (Holes 645A through 645G). Pleistocene sediments were recovered from Holes $645 \mathrm{~A}, 645 \mathrm{~B}, 645 \mathrm{~F}$, and $645 \mathrm{G}$. The stratigraphy of these holes, however, is not discussed as these holes penetrated less than the uppermost $24 \mathrm{~m}$ of the sediment column. Thirty-two XCB cores were recovered from Hole 645B, with a total penetration depth of 298.9 mbsf. Hole 645D was washed to a depth of $265.7 \mathrm{mbsf}$, where drilling began and continued for $20 \mathrm{RCB}$ cores to a total depth of $462.8 \mathrm{mbsf}$. Hole $645 \mathrm{E}$ was also washed to a depth of $301.1 \mathrm{mbsf}$ before coring. Three RCB cores were recovered from 301.1-330.1 mbsf. Washing then continued until 455.2 mbsf, where Cores 105-645E-4R through $-78 \mathrm{R}$ were cored continuously.

The paucity of planktonic microfossils and the limited magnetostratigraphic record resulted in our completing only a tentative stratigraphy that relies on dinocyts and benthic foraminifer age determinations, with occasional determinations from calcareous nannofossil or diatom stratigraphies. The most restricted age ranges possible were assigned to samples based on their microfossil assemblages. We consider the composite stratigraphic section recovered at Site 645 as earliest Miocene to Holocene in age. The occurrence of Multispinula minuta in Cores 105-645B$1 \mathrm{R}$ through $-21 \mathrm{R}$ suggests that the upper $196.8 \mathrm{~m}$ can be assigned a Pleistocene age. Specimens of $M$. minuta have been recorded from Pleistocene sediments in the North Atlantic (Mudie, 1987) and Arctic oceans (Aksu and Mudie, 1985). The co-occurrence of $M$. minuta and Filisphaera filifera in Samples 105-645B-16R, CC to -21R, CC suggests an early Pleistocene age for the interval from 148.8 to 196.8 mbsf. Filisphaera fili- fera has been reported from Pliocene and lower Pleistocene sediments in the North Atlantic (Mudie, 1987) and from upper Miocene to lower Pleistocene sediments in the North Pacific (Bujak, 1984).

The Pliocene/Pleistocene boundary has been tentatively placed at the last common occurrence (LCO) of Cymatiosphaera sp. (referred to as Labyrinthodium sp. in Srivastava, Arthur, et al., $1987)$ in Sample 105-645B-21R, CC (196.8 mbsf). This placement is tenuous because (1) Cymatiosphaera is not a primary stratigraphic marker, (2) although the LCO of this species is recorded in upper Pliocene sediments in the North Atlantic (Mudie, 1987), this species rarely occurs in Holocene sediments (A. de Vernal, pers. comm., 1987), thus, the abundance of the species is most likely ecologically controlled, and (3) the abundance of this species at Site 645 is sporadic in the upper part of its range, preventing an exact placement of this event. Although the above reasons make the placement of the Pliocene/Pleistocene boundary tenuous, the first occurrence (FO) of the Pleistocene species $M$. minuta, also in Sample 105-645B-21R, CC, supports the stratigraphic placement of this boundary.

The occurrence of the calcareous nannofossil Gephyrocapsa sp. in Sample 105-645B-8R, CC and the occurrence of a Pliocene-Pleistocene diatom assemblage in Sample 105-645E-9R, $\mathrm{CC}$ supports a Pliocene or younger age assignment for Cores 105-645B-8R and -9R (62.0-81.3 mbsf).

Sample $105-645 B-31 X, C C$ (292 mbsf) is probably younger than early Pliocene, based on the common occurrence of sinistral specimens of Neogloboquadrina pachyderma, compared with the occurrence of only a few dextral specimens in Cores 105-645B-30X and -31X. Currently, the left-coiling population in the North Atlantic is separated from the right-coiling population by the $7.2^{\circ} \mathrm{C}$ April isotherm (Ericson, 1959). In the Labrador Sea and high Arctic, Bé and Tolderlund (1971) found that $90 \%$ or more of $N$. pachyderma individuals are of the left-coiling variety. The high sinistral-to-dextral ratio observed in samples from Site 645 suggests that these samples are stratigraphically above the coiling change from dextral to sinistral $N$. pachyderma that Berggren (1972) reported as occurring in upper Pliocene sediments from the Labrador Sea. Our placement, however, is tentative because the change in coiling direction may have been missed as a result of the sampling interval or because it occurs in an interval where calcareous microfossils are not preserved.

The rare occurrence of Reticulofenestra pseudoumbilica and Coccolithus pelagicus in occasional samples from Core 105645E-35R through Sample 105-645E-70R-2, 42-44 cm, suggests that the interval from 734.7 to 1063.83 mbsf is early Pliocene to middle Miocene in age and is equivalent to the "Interval with Reticulofenestra pseudoumbilica" of Müller (1976). The occurrence of the benthic foraminifer Melonis zaandamae in Sample $105-645 \mathrm{E}-39 \mathrm{R}, \mathrm{CC}$ and the occurrence of a microfossil of unknown affinity, Bolboforma metzmacheri, in Sample 105-645E$39 \mathrm{X}, \mathrm{CC}$ to $-50 \mathrm{X}, \mathrm{CC}$ suggests that the interval from 772.7 to 884.9 mbsf is early Pliocene to middle Miocene in age. The last occurrence (LO) of B. metzmacheri was found at $753.4 \mathrm{mbsf}$ (Sample 105-645E-36R, CC) by Kaminski et al. (this volume). In the Rockall bank region, this species is not found above nannofossil Zone NN16 (Murray, 1987). In the North Sea, this species defines the late Miocene Zone NSP14 of King (1983). The occurrence of the dinocyst species Palaeocystodinium spp. in the interval from 782 to 1147.1 mbsf suggests an early-late Miocene or older age for Sample 105-645E-45R, CC.

The occurrence of the dinoflagellate Nematosphaeropsis aquaducta in the interval from Sample 105-645E-56R, CC to $-60 \mathrm{R}$, $\mathrm{CC}$ indicates that this interval (936.2-974.9 mbsf) is no older than middle Miocene. Several poorly preserved specimens of Globigerina praebulloides were encountered in Sample 105-654E$67 \mathrm{R}-2,89-91 \mathrm{~cm}$ (1043.5 mbsf). This species is restricted to 


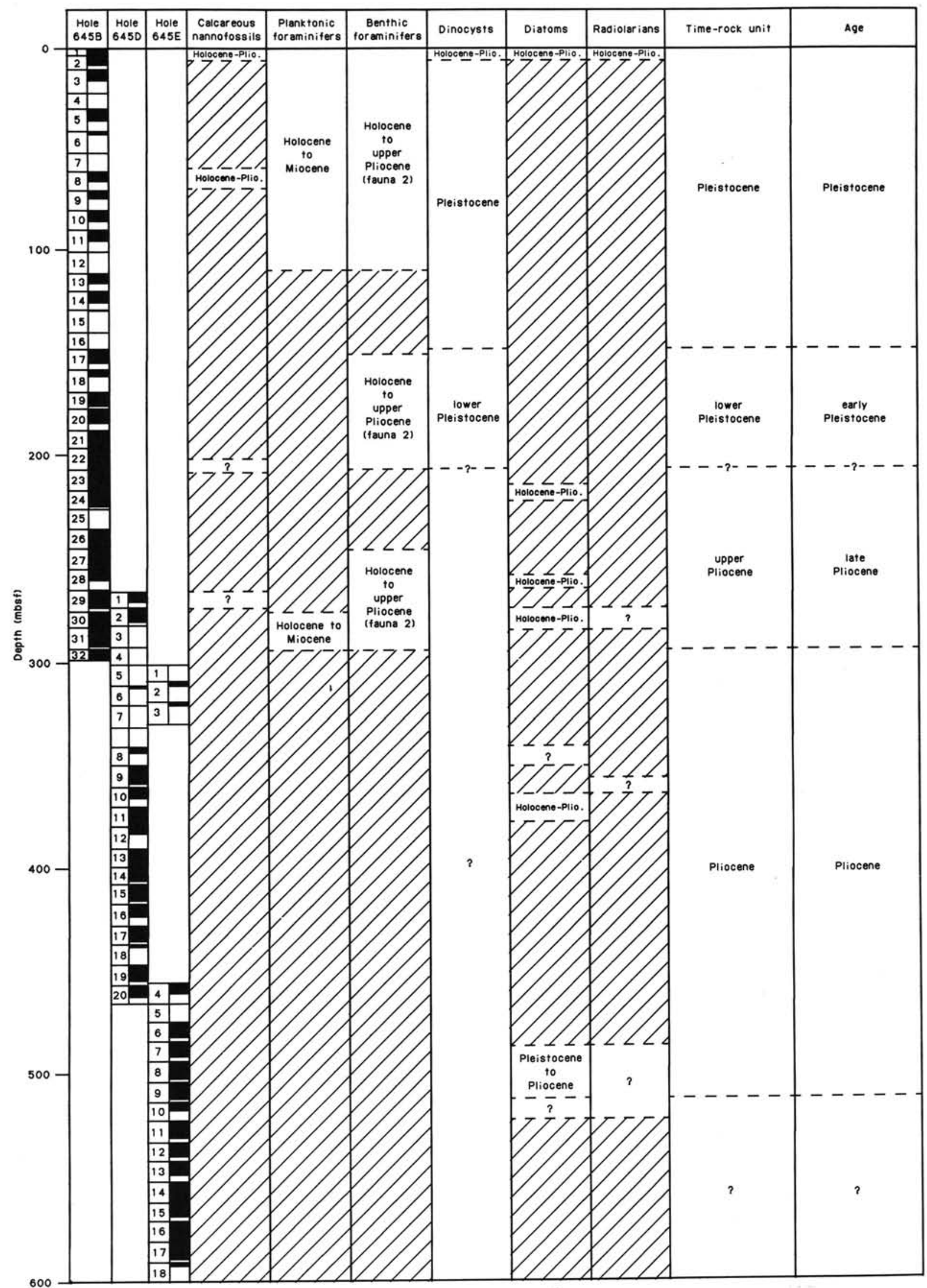

Figure 4. Correlation of coring results at Site 645 (Holes 645A through 645G) with magnetostratigraphy and biostratigraphy of calcareous nannofossils, planktonic foraminifers, dinocysts, diatoms, and radiolarians. Cored interval is in meters; recovered interval is represented by shaded region. Diagonal lines indicate stratigraphic intervals in which the specific microfossils were not observed. 


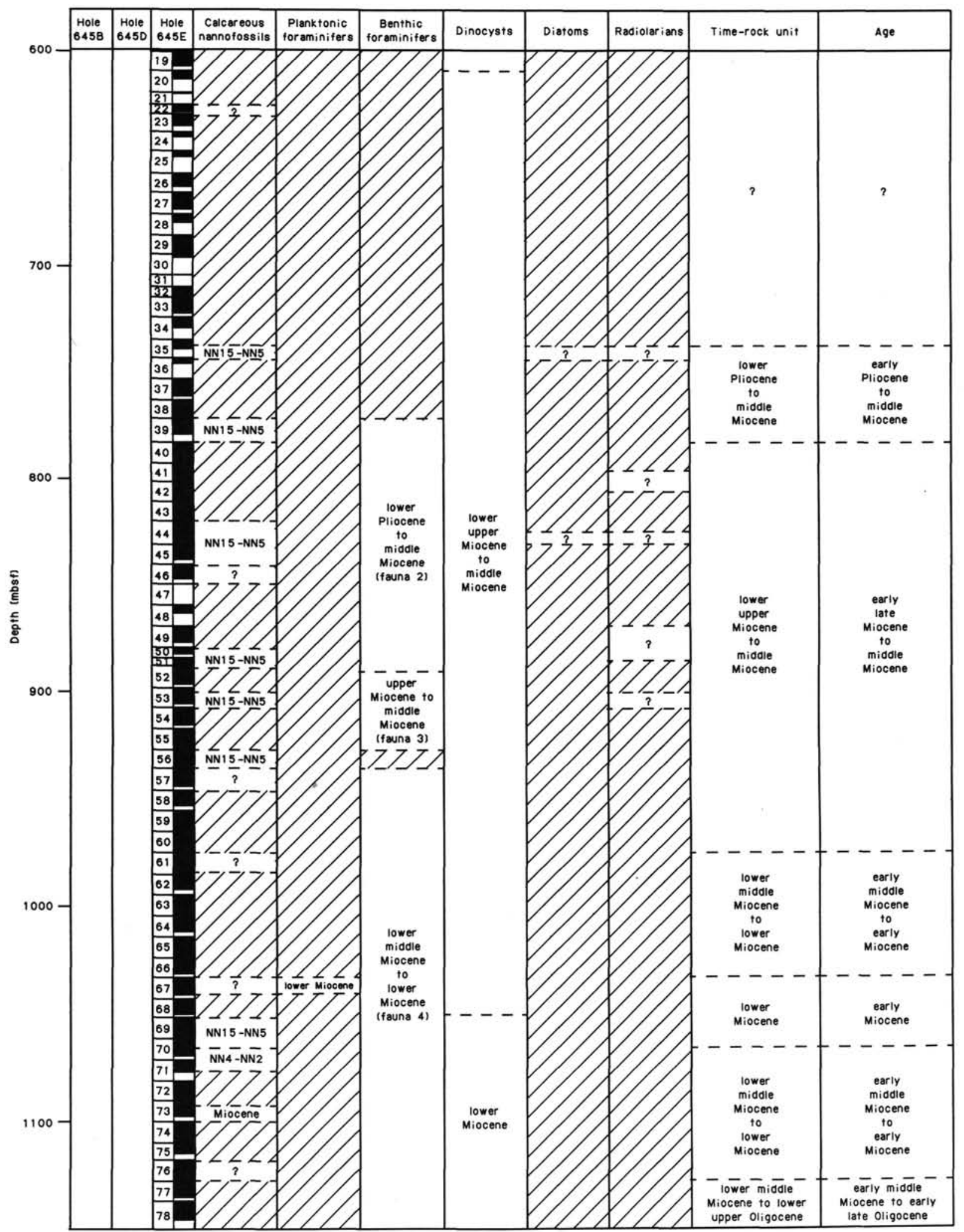

Figure 4. (continued).

lower Miocene to lower-middle Miocene sediments in the North Sea (Gradstein et al., 1988) and lower Miocene sediments on the Labrador Margin (Gradstein and Agterberg, 1982).

The calcareous nannofossil Helicosphaera ampliaperata occurs in Samples 105-645E-70R-5, 61-63 cm, to -71-3, 42-44 cm, and suggests a zonal assignment equivalent to the "Interval with $H$. ampliaperta" of Müller (1976) and to calcareous nannofossil Zones NN2 through NN4. Such a zonal assignment indicates an early Miocene to early-middle Miocene age for this sample interval. Sample 105-645E-73R, CC lacks $H$. ampliaperta, but 
has been assigned an early Miocene age, based on the overall characteristic of the calcareous nannofossil assemblage.

\section{SITE 646}

Site 646 lies in the central Labrador Sea due north of the westernmost terminous of Eirik Ridge in a water depth of $3450.8 \mathrm{~m}$ (Table 1, Fig. 1). The coring record, magnetostratigraphy, biostratigraphic zonations, and microfossil datums with stratigraphic constraints for Holes 646A and 646B are correlated in Table 2 and Figure 5. Two holes were cored at Site 646: Hole 646A consists of 11 APC cores to a depth of 103.5 mbsf and Hole 646B consists of 14 APC cores, followed by $66 \mathrm{XCB}$ cores, to a total depth of $766.7 \mathrm{mbsf}$. The abundance and preservation of microfossils are much improved at this site in comparison to Site 645. As a result, a more reliable chronostratigraphy is defined for Site 646. The one exception is the occurrence of siliceous microfossils, which at Site 646 are restricted to the uppermost 34 cores
(323.4 mbsf). Because of this, the biostratigraphy below this depth relies on calcareous microfossils. The chronostratigraphy at Site 646 is based on 11 paleomagnetic, 12 calcareous nannofossil, 15 foraminifer, and 3 diatom events (Table 2, Fig. 5).

The LCO of the planktonic foraminifer Neogloboquadrina atlantica in Sample 105-646B-20X, CC (188.20 mbsf) and the LO of the calcareous nannofossil Calcidiscus macintyrei between Samples 105-646B-14X, CC and -16X, CC are used to approximate the Pliocene/Pleistocene boundary. However, exact placement of this boundary is not possible because no sediment was recovered from Core 105-646B-15X. Thus, the Pleistocene/ Pliocene boundary has been tentatively placed midway between Core 105-646B-16X and $-14 \mathrm{X}$ and has an estimated depth of 140 mbsf. The LO of Globorotalia margaritae in Sample 105646B-39X-5, 19-24 cm, suggests that the early Pliocene/late Pliocene boundary (as determined by planktonic foraminifers) can be placed at an estimated depth of 369.69 mbsf. However,

Table 2. Biostratigraphic and paleomagnetic events from Site 646.

\begin{tabular}{|c|c|c|}
\hline Event & $\begin{array}{c}\text { Sample } \\
\text { interval }(\mathrm{cm})\end{array}$ & $\begin{array}{l}\text { Depth } \\
\text { (mbsf) }\end{array}$ \\
\hline \multicolumn{3}{|l|}{ Paleomagnetic } \\
\hline $\begin{array}{l}\text { M1 Brunhes/Matuyama } \\
\text { M2 Jaramillo (top) } \\
\text { *M4 Cobb Mountain (top) } \\
\text { *M5 Cobb Mountain (bottom) } \\
\text { M1 Brunhes/Matuyama } \\
\text { M2 Jaramillo (top) } \\
\text { M3 Jaramillo (bottom) } \\
\text { M8 Matuyama/Gauss } \\
\text { M9 Gauss/Gilbert } \\
\text { M10 Chron C4 (top N2) } \\
\text { M11 Chron C4 (bottom N2) } \\
\text { M12 Chron C4A (top N1) } \\
\text { M13 Chron C4A (bottom N1) }\end{array}$ & $\begin{array}{l}\text { A7H-3, } 60-\text { A7H-3, } 87 \\
\text { A8H-5, 145 - A8H-6, } 4 \\
\text { A10H-3, 46-A10H-3, } 80 \\
\text { A10H-4, 3-A10H-4, } 46 \\
6 \mathrm{H}-6,120-8 \mathrm{H}-6,78 \\
9 \mathrm{H}-3,120-9 \mathrm{H}-3,140 \\
9 \mathrm{H}-7,30-10 \mathrm{H}-2,10 \\
21 \mathrm{X}-2,69-21 \mathrm{X}-3,141 \\
31 \mathrm{X}-6,65-31 \mathrm{X}-6,75 \\
66 \mathrm{X}-3,4-67 \mathrm{X}-1,38 \\
70 \mathrm{X}-1,70-71 \mathrm{X}-1,114 \\
72 \mathrm{X}-1,36-72 \mathrm{X}-2,81 \\
74 \mathrm{X}-4,35-75 \mathrm{X}-1,79\end{array}$ & $\begin{array}{c}58.70-58.97 \\
72.25-72.34 \\
87.56-87.90 \\
88.63-89.06 \\
52.10-73.86 \\
76.60-76.80 \\
81.70-83.60 \\
190.40-192.60 \\
292.85-292.95 \\
625.24-632.18 \\
661.60-671.34 \\
680.06-682.01 \\
702.85-708.39\end{array}$ \\
\hline \multicolumn{3}{|l|}{ Calcareous nannofossils } \\
\hline $\begin{array}{l}\text { N1 FO Emiliania huxleyi } \\
\text { N2 LO Pseudoemiliania lacunosa } \\
\text { N3 LO Calcidiscus macintyrei } \\
\text { N5 Occ. Discoaster brouweri } \\
\text { N6 LO Discoaster surculus } \\
\text { N7 LCO Reticulofenestra pseudoumbilica } \\
\text { N8 FO P. lacunosa } \\
\text { N9 FO Ceratolithus rugosus } \\
\text { N10 LO Discoaster quinqueramus } \\
\text { N11 FO D. surculus } \\
\text { N12 Occ. Amaurolithus primus } \\
\text { N13 FO D. quinqueramus }\end{array}$ & $\begin{array}{l}\text { A2H-5, 102-104-A2H-6, } 104-106 \\
\text { A4H-5, 96-98- A4H-6, 96-98 } \\
14 \mathrm{X}, \mathrm{CC}-16 \mathrm{X}, \mathrm{CC} \\
18 \mathrm{X}-2,118-120-18 \mathrm{X}-3,40-42 \\
22 \mathrm{X}, \mathrm{CC}-23 \mathrm{X}-1,62-64 \\
37 \mathrm{X}-1,103-105-37 \mathrm{X}-2,103-105 \\
41 \mathrm{X}-343-45-41 \mathrm{X}-4,43-45 \\
46 \mathrm{X}-2,25-27-46 \mathrm{X}, \mathrm{CC} \\
52 \mathrm{X}, \mathrm{CC}-53 \mathrm{X}, \mathrm{CC} \\
55 \mathrm{X}, \mathrm{CC}-56 \mathrm{X}, \mathrm{CC} \\
60 \mathrm{X}, \mathrm{CC}-61 \mathrm{X}-1,85-87 \\
75 \mathrm{X}-1,108-110-75 \mathrm{X}-2,41-43\end{array}$ & $\begin{array}{c}12.03-13.55 \\
32.99-34.47 \\
130.00-149.80 \\
161.70-162.51 \\
207.50-208.13 \\
343.84-345.34 \\
384.44-385.94 \\
431.56-439.50 \\
497.10-506.90 \\
526.20-535.80 \\
574.00-574.85 \\
709.69-710.50\end{array}$ \\
\hline \multicolumn{3}{|l|}{ Planktonic foraminifers } \\
\hline $\begin{array}{l}\text { F2 LO Neogloboquadrina atlantica } \\
\text { F3 FO Globorotalia inflata } \\
\text { F4 FO enc. N. pachyderma } \\
\text { F5 LCO N. atlantica } \\
\text { F7 FO Globigerina umbilicata } \\
\text { F8 LCO N. humerosa } \\
\text { F9 LO Globigerina woodi } \\
\text { F10 LO Globoquadrina venezuelana } \\
\text { F11 LO Globorotalia punticulata } \\
\text { F12 LO Globorotalia margaritae } \\
\text { F13 FO Globorotalia puncticulata } \\
\text { F14 LCO N. acostaensis } \\
\text { F15 FO Globorotalia margaritae } \\
\text { F16 LO N. continuosa } \\
\text { F17 D-S N. atlantica }\end{array}$ & $\begin{array}{l}14 \mathrm{H}-5,81-83-16 \mathrm{X}, \mathrm{CC} \\
17 \mathrm{X}, \mathrm{CC}-18 \mathrm{X}-1,40-42 \\
18 \mathrm{X}-2,44-46-18 \mathrm{X}-3,28-33 \\
20 \mathrm{X}-4,27-32-20 \mathrm{X}, \mathrm{CC} \\
26 \mathrm{X}, \mathrm{CC}-28 \mathrm{X}, \mathrm{CC} \\
29 \mathrm{X}-1,40-45-29 \mathrm{X}-2,40-45 \\
30 \mathrm{X}-1,39-44-30 \mathrm{X}-2,39-44 \\
30 \mathrm{X}-1,39-44-30 \mathrm{X}-2,39-44 \\
36 \mathrm{X}-1,82-87-36 \mathrm{X}-2,71-76 \\
39 \mathrm{X}-5,11-13-39 \mathrm{X}-5,19-24 \\
41 \mathrm{X}-2,26-30-41 \mathrm{X}-3,27-31 \\
50 \mathrm{X}, \mathrm{CC}-51 \mathrm{X}-1,107-112 \\
53 \mathrm{X}, \mathrm{CC}-54 \mathrm{X}, \mathrm{CC} \\
62 \mathrm{X}, \mathrm{CC}-63 \mathrm{~K}-1,46-50 \\
78 \mathrm{~K}-2,8-10-78 \mathrm{~K}, \mathrm{CC}\end{array}$ & $\begin{array}{l}127.62-149.80 \\
159.10-159.51 \\
161.05-162.40 \\
183.30-188.20 \\
246.00-265.30 \\
265.72-267.20 \\
275.42-276.89 \\
275.42-276.89 \\
331.95-335.31 \\
368.12-369.69 \\
383.08-384.59 \\
478.10-479.11 \\
506.90-516.50 \\
593.20-593.66 \\
739.28-747.40\end{array}$ \\
\hline \multicolumn{3}{|l|}{ Diatoms } \\
\hline D1 LO Rhizolenia curvirostris & $1 \mathrm{H}, \mathrm{CCH}-1,128-130$ & $9.00-15.69$ \\
\hline \multicolumn{3}{|l|}{ Radiolarians } \\
\hline FAD C. Davisiana & $25 \mathrm{X}, \mathrm{CC}-26 \mathrm{X}-2,20-22$ & 246.0 \\
\hline
\end{tabular}

Note: Events are from Hole 646B unless otherwise indicated. ${ }^{*}$ Not shown in Figure 5. 
G. margaritae is a low-latitude species and its LO has been shown to be diachronous in the North Atlantic (Weaver and Clement, 1986).

The calcareous nannofossil Discoaster quinqueramus has a last consistent occurrence in Sample 105-646B-53X, CC (506.90 mbsf) and the FO of $G$. margaritae is found in Sample 105646B-54X, CC (516 mbsf). Both of these events pre-date by $0.3 \mathrm{Ma}$ the Miocene/Pliocene boundary (Berggren et al., 1985a), which suggests that the Miocene/Pliocene boundary can be placed above these samples. Previous studies (Berggren et al., 1985a) indicated that these two events are isochronous, which agrees with biostratigraphic results in Hole 646B, given the resolution of sampling over this interval of low core recovery. Thus, placement of the Miocene/Pliocene boundary can only be estimated and was determined as occurring at a depth of about 477.0 mbsf.

The FO of D. quinqueramus in Sample 105-646B-75X-1, $108-110 \mathrm{~cm}$, indicates that the stratigraphic sequence below this interval is equivalent to or older than calcareous nannofossil Zone NN10. Paleomagnetic results indicate that the top of Chronozone C5N may be located in the lowermost part of Core 105646B-78X. These stratigraphic markers suggest that the lowermost part of the Hole 646B sedimentary sequence has a late Miocene age.

\section{SITE 647}

Site 647 is located in the southern Labrador Sea in a water depth of $3861.8 \mathrm{~m}$ (Table 1, Fig. 1). Two holes were cored at Site 647: Hole 647A was rotary cored to a depth of $736.0 \mathrm{mbsf}$ and Hole $647 \mathrm{~B}$ was piston cored to a depth of $103.3 \mathrm{mbsf}$. The recovered sequence is fossiliferous, with calcareous nannofossils present throughout most of the sequence. Siliceous microfossils occur much less frequently and are restricted to the interval from 120 through 270 mbsf. Planktonic foraminifers also have a restricted stratigraphic range and occur only in the upper $117 \mathrm{~m}$. The stratigraphic sequence is early Eocene to Holocene in age.

The coring record, magnetostratigraphy, biostratigraphic zonations, and microfossil datums with stratigraphic constraints for Holes 647A and 647B are correlated in Table 3 and Figure 6. The Zone N21/Zone N22 boundary has been placed at 68.0 mbsf, based on the FO of Globorotalia truncatulinoides in Sample 105-647A-7R, CC (Aksu and Kaminski, this volume). The FO of this species has been found to be diachronous in the North Atlantic (Weaver and Clement, 1986; Baldauf et al., 1987) and was dated at $1.35 \mathrm{Ma}$ at Site 611 in the eastern North Atlantic. The first appearance datum (FAD) of $G$. truncatulinoides at Site 647 was determined as $1.25 \mathrm{Ma}$, based on interpolation using magnetostratigraphy (Aksu and Kaminski, this volume). The Pliocene/Pleistocene boundary was tentatively placed below Core 105-647A-8R at a depth of about 73 mbsf. This stratigraphic placement is supported by the LO of Calcidiscus macintyrei in Sample 105-647A-9R-1, 49-51 cm. The early middle Pleistocene boundary coincides with the Brunhes/Matuyama boundary at a depth of 32.06 mbsf (Section 647A-12R-3, CC).

The lower portion of Core 105-647A-12R is placed in the upper Pliocene Discoaster surculus Zone (NN16), based on the occurrence of $D$. surculus without Reticulofenestra pseudoumbil$i c a$. However, extremely rare specimens of $R$. pseudoumbilica occur in Sample 105-647A-12R, CC, suggesting that the base of this zone could be placed slightly higher. The LO of Neogloboquadrina atlantica was found in Sample 105-647A-12, CC, suggesting that the base of the upper Pliocene section overlying the hiatus at $117 \mathrm{mbsf}$ is older than $2.3 \mathrm{Ma}$, based on the FAD of $N$. atlantica in DSDP Leg 94 holes in the eastern Atlantic (Weaver and Clement, 1986; Baldauf et al., 1987). However, the underlying samples (uppermost part of Core 105-647A-13R) contain rare specimens of Discoaster quinqueramus and Disco- aster bollii, which allowed us to assign the upper portion of this core to the Discoaster calcaris/D. quinqueramus zones (NN10/ NN11). This zonal placement indicates a temporal break between Cores $105-647 \mathrm{~A}-12 \mathrm{R}$ and $-13 \mathrm{R}$ that has a minimum estimated duration of $2 \mathrm{Ma}$.

With the exception of Sample 105-647A-14R-1, 59-62 cm, the remaining samples from Core 105-647A-13R and those samples examined from Core 105-647A-14R are barren of calcareous microfossils. Sample 105-647A-14R-1, 59-62 cm, contains rare and poorly preserved specimens of Reticulofenestra bisecta, which suggests an Oligocene age. Siliceous microfossils first occur in Core 105-647A-13R. The occurrence of single specimens of the diatom Coscinodiscus lewisianus in Samples 105-647A$13 \mathrm{R}-5,109-111 \mathrm{~cm}$, and $-13 \mathrm{R}, \mathrm{CC}$ and a single specimen of Rocella gelida in Sample 105-647A-14R-3, 6-8 cm, suggests that this interval is equivalent in age to the latest Oligocene to earliest Miocene. The occurrence of the radiolarians Cyrtocapsella tetrapera, Cyrtocapsella cornuta, Calocycletta robusta, Stichocorys delmontense, and Eucyrtidium diaphanes(?) suggests that Samples 105-647A-13R, CC through -14R, CC are equivalent to the $S$. delmontensis to upper $L$. elongata zones of Riedel and Sanfilippo (1978) (Srivastava, Arthur, et al., 1987) and are early Miocene in age.

Core $105-647 \mathrm{~A}-15 \mathrm{R}$ is assigned to calcareous nannofossil Zone NP24 and to an interval equivalent to the lower part of the Rocella vigilans diatom Zone of Fenner (1984). The NP23/NP24 boundary is tentatively placed between Samples 105-647A-16R$3,36-38 \mathrm{~cm}$ (148.4 mbsf) and -16R, CC (154.8 mbsf) and suggests that Core $105-647 \mathrm{~A}-15 \mathrm{R}$ is equivalent to the lowermost part of Zone NP24. This zonal assignment is supported by the diatom stratigraphy, which suggests that this core is equivalent to the lower portion of the $R$. vigilans Zone. Thus, the stratigraphic evidence suggests that Core $105-647 \mathrm{~A}-15 \mathrm{R}$ is equivalent to the uppermost lower Oligocene. This age assignment indicates that a hiatus, having a duration of about $7 \mathrm{Ma}$ occurs between Samples 105-647A-14R, CC and -15R-1, 68-70 cm.

The remaining cored interval represents a continuous sequence from the lower Eocene to the lower Oligocene. Several of the planktonic foraminiferal taxa, whose first and last occurrences have been correlated to the polarity time scale in low-latitude biostratigraphic sequences (Berggren et al., 1985b), occur in the Oligocene and upper Eocene of Hole 647A. However, their positions in Hole 647A do not always agree with their expected position in terms of nannofossil biostratigraphy. This apparent diachrony is not unexpected because the stratigraphic ranges of low-latitude species are often truncated at high latitudes.

The LO of Subbotina angiporoides was observed in Sample 105-647A-20R-2, 90-93 cm. This event has been correlated to the base of Chronozone CIIN (32.0 Ma) by Berggren et al. (1985b). Both the LO of Chiloguembelina (Zone P2la/Zone P2lb boundary; $30.0 \mathrm{Ma}$ ) and the LO of Globigerina ampliapertura (Zone P19/Zone P20 boundary; $32.8 \mathrm{Ma}$ ) occur in Sample $105-647 \mathrm{~A}-27 \mathrm{R}-1,78-83 \mathrm{~cm}$. Even allowing for the fact that only drilling slurry was recovered in Core 105-647A-26R which was not sampled for foraminifers, the LOs of both taxa are anomalously low when compared with nannofossil biostratigraphy. The Eocene/Oligocene boundary is tentatively placed between Samples 105-647A-30R-7, $48 \mathrm{~cm}$ and $-30, \mathrm{CC}$, based on the LO of Discoaster barbadiensis. The placement of this boundary also agrees well with the change in the benthic foraminifers, which correlates with the Eocene/Oligocene transition. The LOs of both Reticulophragmium amplectems and Spiroplectammina spectabilis were observed in Sample 105-647A-31R-1, 132-135 cm. These species were used to determine the Eocene/Oligocene boundary in the Norwegian-Greenland Sea (Verdenius and van Hinte, 1983). The LOs of two planktonic foraminiferal species used to determine the Eocene/Oligocene boundary in low-lati- 


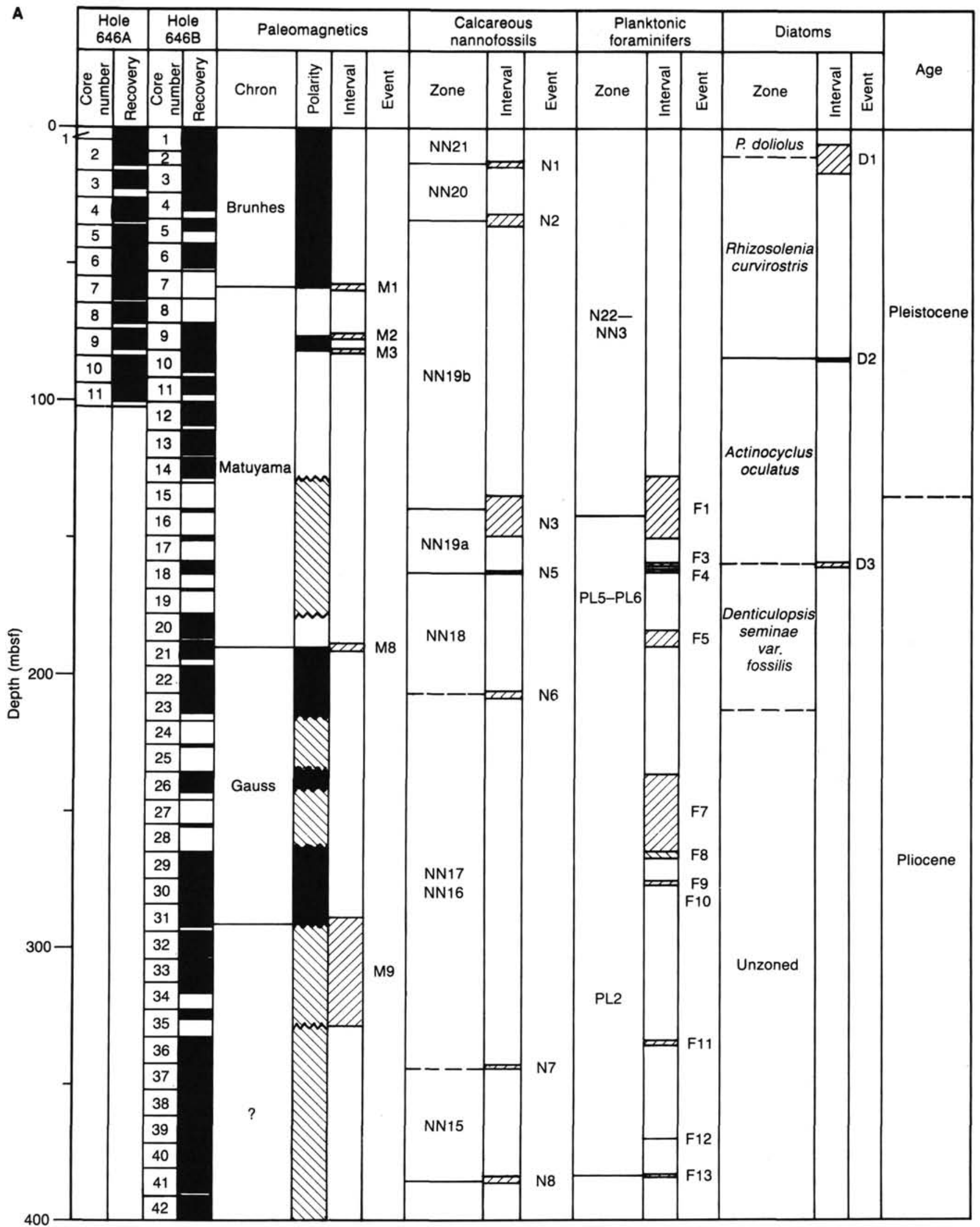

Figure 5. Correlation of coring results at Site 646 (Holes 646A and 646B) with magnetostratigraphy and biostratigraphy of calcareous nannofossils, planktonic foraminifers, and diatoms. Biostratigraphic events are indicated; the hatched area indicates depth range of the stratigraphic events. For an explanation of the event numbers, see Table 2 . Core recovery and normal polarity intervals shown in black. 


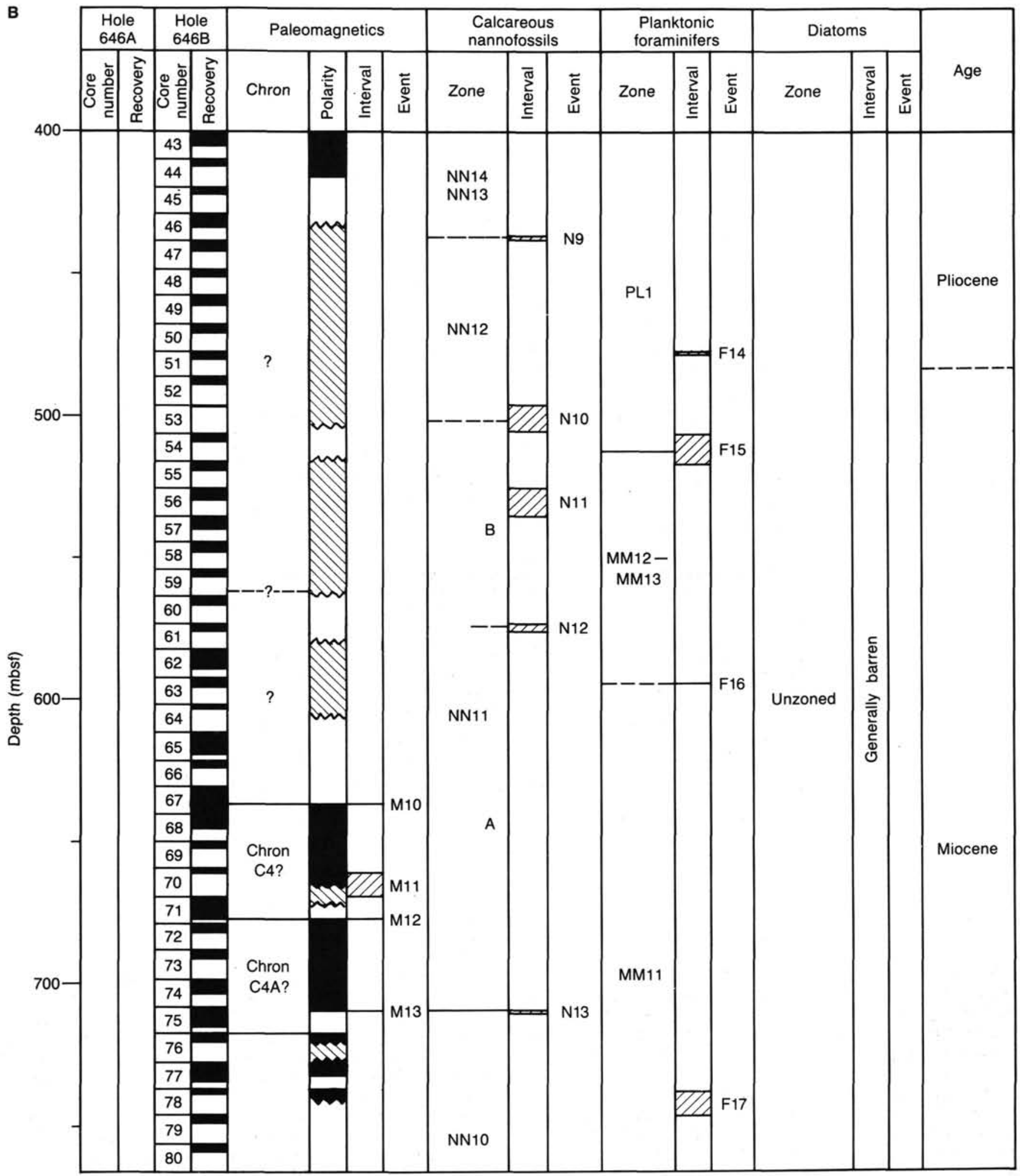

Figure 5 (continued).

tude sequences are significantly offset with respect to nannofossils and benthic foraminifers. The LO of Hantkenina occurs in Sample 105-647A-39, CC, and the LO of Turborotalia cerroazulensis was observed in Sample 105-647A-35R-3, 77-80 cm. A potentially useful upper Eocene marker species in Hole $647 \mathrm{~A}$ is the LO of Globigerinatheka index in Sample 105-647A-36R-3,
49-52 cm. Berggren et al. (1985b) dated this event to occur at $37.0 \mathrm{Ma}$ at low latitudes.

The Zone NP17/Zones NP18-NP20 boundary is recognized by the first occurrence of Chiasmolithus oamaruensis. This boundary occurs between Samples 105-647A-46R-3, 33-35 cm, and 46R-4, 101-103 cm. The middle/late Eocene boundary (as de- 
Table 3. Site 647 biostratigraphic and paleomagnetic events.

\begin{tabular}{|c|c|c|}
\hline Event & $\begin{array}{c}\text { Sample } \\
\text { interval }(\mathrm{cm})\end{array}$ & $\begin{array}{l}\text { Depth } \\
\text { (mbsf) }\end{array}$ \\
\hline \multicolumn{3}{|l|}{ Paleomagnetic } \\
\hline M1 Base of Brunhes & $4 \mathrm{H}-5,86-88-4 \mathrm{H}-6,28-30$ & $32.06-33.88$ \\
\hline M2 Top of Jaramillo & $5 \mathrm{H}-5,26-28-5 \mathrm{H}-5,88-90$ & $42.06-42.68$ \\
\hline M3 Base of Jaramillo & $5 \mathrm{H}-6,88-90-6 \mathrm{H}-3,130-132$ & $44.18-49.80$ \\
\hline M6 Top of Olduvai & $9 \mathrm{H}-4,130-132-9 \mathrm{H}-5,25-27$ & $80.10-80.55$ \\
\hline M7 Base of Olduvai & $10 \mathrm{H}-2,80-82-10 \mathrm{H}-3,32-34$ & $86.20-7.22$ \\
\hline M8 Base of Matuyama & A12R-3, 15-17 - A12R-3, 25-27 & 109.84-109.94 \\
\hline M14 Chron C18 & $47 \mathrm{R}-5,48$ & 450.75 \\
\hline M15 Chron C19 (top N1) & 50R-6, 145 & 481.45 \\
\hline M16 Chron C19 (bottom N1) & $51 \mathrm{R}-6,55$ & 490.15 \\
\hline \multicolumn{3}{|l|}{ Calcareous nannofossils } \\
\hline N1 LO Emiliania huxleyi & $1 \mathrm{H}-6,130-132-1 \mathrm{H}-7,14-16$ & \\
\hline N2 LO Pseudoemiliania lacunosa & $2 \mathrm{H}, \mathrm{CC}-4 \mathrm{H}-1,138-140$ & \\
\hline N3 LO C. macintyrei & $8 \mathrm{R}, \mathrm{CC}-9 \mathrm{R}-1,49-51$ & \\
\hline $\begin{array}{l}\text { N4 LO D. triradiatus and } D . \text { brouweri } \\
\text { N5 }\end{array}$ & $10 \mathrm{R}-2,45-47-10 \mathrm{R}-3,45-47$ & \\
\hline N10 LO D.quinqueramus & $12 \mathrm{H}, \mathrm{CC}-13 \mathrm{H}-1,53-55$ & \\
\hline $\begin{array}{l}\text { N14 Occ. Reticulofenestra bisecta, } \\
\text { Cyclicargolithus abisectus, and } C . \\
\text { floridanus }\end{array}$ & $14 R-1,59-61-15 R-1,68-70$ & $126.30-136.09$ \\
\hline N15 Occ. Shenolithus ciperoensis & $16 \mathrm{R}-3,36-38-17 \mathrm{R}-1,116-118$ & 148.37-155.97 \\
\hline N16 LO Reticulofenestra umbilica & $23 \mathrm{R}-1,118-120-23 \mathrm{R}-2,110-112$ & $213.49-214.61$ \\
\hline N17 LO Ericsonia formosa & $25 \mathrm{R}-5,61-63-27 \mathrm{R}-1,51-53$ & $237.60-250.92$ \\
\hline N18 LO Discoaster barbadensis & 30R-7, 17-18 - 30R-7, 48 & 288.57-288.88 \\
\hline N19 FO Chiasmolithus oamaruensis & $46 \mathrm{R}-3,33-35-46 \mathrm{R}-4,101-103$ & 437.14-439.32 \\
\hline N23 LO C. solitus & $47 R-6,42-44-48 R-1,91-93$ & $452.14-454.12$ \\
\hline $\begin{array}{l}\mathrm{N} 24 \text { Occ. } R . \text { umbilica } \mathrm{w} / \text { Toweius } \\
\text { pertusus, } T . \text { callosus, and Nanno- } \\
\text { tetring eristata }\end{array}$ & $56 \mathrm{R}, \mathrm{CC}-57 \mathrm{R}, \mathrm{CC}$ & $540.00-549.70$ \\
\hline N25 Occ. Chiasmolithus gigas & $62 R-1,36-38$ & 607.35 \\
\hline N26 LO Discoaster lodensis & $63 R-1,36-38-66 R-1,52-54$ & $608.17-637.33$ \\
\hline N28 LO Tribrachiatus orthostylus & $66 \mathrm{R}-2,49-51-67 \mathrm{R}-1,140-142$ & 638.80-647.91 \\
\hline N29 FO $D$. lodensis & $69 \mathrm{R}, \mathrm{CC}-70 \mathrm{R}-1,47-49$ & $675.50-685.68$ \\
\hline \multicolumn{3}{|l|}{ Planktonic foraminifers } \\
\hline F1 FO Gr. truncatulinoides & $7 \mathrm{R}, \mathrm{CC}-8 \mathrm{R}-1,21-26$ & $68.00-68.23$ \\
\hline F3 FO Gr. inflata & $11 \mathrm{R}, \mathrm{CC}-12 \mathrm{R}-1,33-38$ & $106.70-107.05$ \\
\hline F6 FO Gr. crassaformis & $12 \mathrm{R}, \mathrm{CC}-13 \mathrm{R}-2,16-21$ & $116.00-117.69$ \\
\hline F18 LO Subbotina angiporoides & $20 \mathrm{R}-1,91-94-20 \mathrm{R}-2,93-96$ & 184.41-185.95 \\
\hline F19 LO Chiloguembelina & $25 R-4,107-110-27 R-1,78-83$ & 237.08-251.18 \\
\hline F20 LO Globigerina ampliapertura & $25 \mathrm{R}-4,107-110-27 \mathrm{R}-1,78-83$ & $237.08-251.18$ \\
\hline F21 LO Pseudohastigerina & $31 \mathrm{R}-1,132-135-31 \mathrm{R}-2,34-37$ & $290.32-290.85$ \\
\hline F22 LO Turborotalia cerroazulensis & $35 \mathrm{R}-1,77-80-35 \mathrm{R}-3,77-80$ & 328.38-331.38 \\
\hline F23 LO Hantkenina & $39 \mathrm{R}-3,77-80-39, \mathrm{CC}$ & $369.88-375.70$ \\
\hline F24 LO Acarinina & $48 \mathrm{R}-5,104-107-49 \mathrm{R}-1,118-121$ & $460.25-464.00$ \\
\hline F25 FO Subbotina frontosa & $62 R-6,22-25-63 R-1,139-142$ & $605.83-609.20$ \\
\hline F26 LO Acarinina pentacamerata & $67 R-3,36-39-68-1,129-132$ & $649.87-657.50$ \\
\hline \multicolumn{3}{|l|}{ Diatoms } \\
\hline D7 LO Coscinodiscus excavatus & $23 R-2,57-59-23 R-4,100-102$ & 214.38-217.01 \\
\hline D8 LO Cestodiscus reticulatus & $23 R-2,57-59-23 R-4,100-102$ & 214.38-217.01 \\
\hline \multicolumn{3}{|l|}{ Radiolarians } \\
\hline FAD C. davisiana & $25 \mathrm{X}, \mathrm{CC}-26 \mathrm{X}-2,20-22$ & 246.0 \\
\hline
\end{tabular}

Note: Events are from Hole 647A unless otherwise indicated.

termined by calcerous nannofossils) is placed directly below this sample interval and thus occurs at an estimated depth of 440 mbsf. The placement of the middle/late Eocene boundary is supported by the LO of Acarinia in Sample 105-647A-49R-1, $118-121 \mathrm{~cm}$. Berggren et al. (1985b) determined that this event occurred at $40.6 \mathrm{Ma}$ at low latitudes.

The early/middle Eocene boundary cannot be determined precisely at Site 647 because it is contained within an interval (608-646 mbsf) that is barren of calcareous nannofossils. This interval separates sediment correlated with calcareous nannofossil Zone CP13b (Okada and Bukry, 1980; equivalent to NP15 of Martini, 1971) (Sample 105-647A-63R-1, 36-38 cm) from sediment assigned to calcareous nannofossil Zone CPll (Okada and Bukry, 1980; equivalent to Zone NP15 of Martini, 1971) below (Sample 105-647A-66R-1, 52-54 cm). However, the noncalcareous interval between 608 and 646 mbsf contains an agglutinated foraminiferal assemblage dominated by species of Glomospira (Kaminski et al., this volume). A similar Glomospira assemblage occurs in deep-water sediments of the Alpine areas of southern Europe, where it is a widely recognized lower Eocene correlation zone. In the Polish Carpathians, the upper limit of its age has been determined to occur within Zone NP14 (Olszewska and Smagowicz, 1977). Beneath the Glomospira assemblage, planktonic foraminifers occur abundantly and are dominated by Subbotina patagonica. The $S$. patagonica Zone occurs widely in the northern Atlantic and correlates with Zones P7 and P8 (Berggren and Schnitker, 1983).

The lowermost stratigraphic sequence at Site 647 (Sample $105-647 \mathrm{~A}-71 \mathrm{R}-2,41 \mathrm{~cm}$ ) is assigned to calcareous nannofossil Zone NP11, based on the occurrence of Tribrachiatus orthostylus without $T$. contortus and $D$. lodoensis. This sample is immediately above basement and allows one to assign an early Eocene or older age to basement.

\section{REEVALUATION OF DSDP SITE 112}

\section{Biostratigraphy}

The stratigraphic sequence recovered from Hole 647A (with its abundant microfossils) resulted in a well-defined biostratigraphy for the Eocene and lower Oligocene. This stratigraphy 
can be directly correlated to DSDP Site 112 and allows us to reevaluate the biostratigraphies previously completed for Site 112 .

Site 112 is situated about $60 \mathrm{n}$. mi. northwest of Site 647 in a water depth of $3657 \mathrm{~m}$. Site 112 sediments were previously examined for foraminifers, calcareous nannofossils, radiolarians, and diatoms (Laughton, Berggren, et al., 1972). More recently, the sequence from Site 112 was reexamined by Miller et al. (1985). However, noncontinuous coring of the sedimentary sequence limited the previous stratigraphic study of Site 112 sediments (Laughton, Berggren, et al., 1972). Thus, the Eocene to lower Oligocene stratigraphic sequence recovered from Site 647 provides a continuous sequence for calibration and for reevaluating the previously documented Paleogene stratigraphy of Site 112.

The coring record, biostratigraphic zonations, and microfossil datums with stratigraphic constraints for Holes 112 and $112 \mathrm{~A}$ are correlated in Figure 7 and Table 4. Samples were examined for Paleogene calcareous nannofossils and for Paleogene and Neogene diatoms and benthic foraminifers. As at Hole $647 \mathrm{~A}$, calcareous nannofossils are represented throughout the recovered stratigraphic sequence. Siliceous microfossils (specifically diatoms) are present in Cores 12-112-5R through -llR. This stratigraphic interval (270-333 mbsf) is assigned to Zone NP23, based on calcareous nannofossils, and to an interval equivalent to the Rocella vigilans Zone and the Cestodicus reticulatus- $R$. vigilans Zone, based on diatoms. The benthic foraminiferal assemblage in Core 12-112-11R corresponds to the calcareous benthic foraminifer Turrilina alsatica assemblage of Kaminski et al. (this volume) in Hole 647A. The diverse nature of the foraminiferal assemblage and good preservation present in Sample 12-112$11 \mathrm{R}-2,102-106 \mathrm{~cm}$, are comparable only to the assemblages above the siliceous sediments of lithologic Unit IIIB in Hole 647A. The composition of the foraminiferal assemblage compares best with that of assemblages from Core 105-647A-17R. Therefore, Cores 12-112-5R through $-11 \mathrm{R}$ are late-early Oligocene in age. This interval correlates in age with the lower part of Core 105-647A-16R through approximately Core 105-647A-19R.

After reevaluating, Core 12-112-12R is assigned to Zone NP22 (lower Oligocene), based on the occurrence of Reticulofenestra umbilica without the occurrence of Ericsonia formosa. This age assignment differs from that of Perch-Nielsen (1972) and Bukry (1972), but is corroborated by Aubry (1982) and by benthic foraminifers. Sample 12-112-12R-1, 44-46 cm, contains a planktonic foraminiferal assemblage with Chiloguembelina, Pseudohastigerina, and Bolboforma irregularis. At Site 647, the LOs of Chiloguembelina and B. irregularis were found in Sample 105647A-27R-1, 78-85 cm. However, the only flysch-type agglutinated species present in Sample 112-12R-1, 44-46 cm, is Rhabdammina sp. The lack of Ammodiscus latus and Glomospira charoides in this sample indicates that it belongs in the Turrilina alsatica assemblage of Kaminski et al. (this volume) and probably correlates with the unsampled interval between Cores 105 647A-25R and -27R in Hole 647A. Core 12-112-13R is assigned to Zone NP18-20, which allows us to place the Eocene/Oligocene boundary between Cores 12-112-12R and -13R. The stratigraphic position of Core 12-112-13R can be further constrained using benthic foraminifers. Core 12-112-13R contains both $\mathrm{Am}$ mosphaeroidina and Karreriella coniformis, species that disappear in the upper Eocene of Hole 647A. Thus, Core 12-11213R, correlates with the lower part of the Reticulophragmium amplectens assemblage of Hole 647A (Kaminski et al., this volume). The absence of Nuttallides truempyi in Core 12-112-13R indicates that this core correlates with Cores 105-647A-36R to $-40 \mathrm{R}$. The middle/late Eocene boundary is placed between Cores 12-112-13R and -14R, based on the calcareous nannofossil stratigraphy by which we assign Core $12-112-13 R$ to Zones
NP18-NP20 and Core 12-112-14R to Zones NP16-NP17. Core $12-112-15 \mathrm{R}$ was originally assigned to Zone NP14, based on the occurrence of Rhabdosphaera inflata (Bukry, 1972). The topmost part of this core (Sample 12-112-15-1, 6-10 cm) is assigned to Zone NP15, based on its stratigraphic position above the LO of $R$. inflata. The base of the hole (Core 12-112-16R) was barren of calcareous nannofossils and could not be dated. The presence of the benthic foraminifer Rzchakina epigona and Saccamminea placenta indicated a Paleocene age. On the Labrador margin, these species are not found above the Paleogene.

\section{Sedimentation Rates}

The sedimentation-rate curves for Sites 646 and 647 are shown in Figures 8 and 9, and the datums used to construct these curves are given in Tables 2 and 3. Because of the limited number of biostratigraphic events, the sedimentation-rate curves are constrained, where possible, by the magnetostratigraphy.

Sixteen biostratigraphic and 10 magnetostratigraphic events constrain the sedimentation-rate curve at Site 646 . With the exception of the interval from 672 and 682 mbsf, the resulting curve, although tenuous, suggests sedimentation rates between 72 and $100 \mathrm{~m} / \mathrm{m}$.y. Between 672 and $682 \mathrm{mbsf}$, the sedimentation rate abruptly declines, which suggests either an extremely low rate of deposition $(17 \mathrm{~m} / \mathrm{m}$.y.) or the occurrence of a hiatus ( $0.75 \mathrm{Ma}$ duration).

Several of the biostratigraphic events, such as the LOs of $N$. atlantica and $G$. margaritae and the FOs of $G$. umbilicata and Pseudoemiliania lacunosa, fall off the sedimentation-rate curve, which suggests ages that are slightly diachronous $(<1 \mathrm{Ma})$ to those determined by Berggren et al. (1985). Similar results were recorded by Baldauf et al. (1987) at nearby Site 611 for several of the above events.

Twenty-six biostratigraphic and eight magnetostratigraphic events were recognized at Site 647 and used to constrain the sedimentation-rate curve. The resulting curve has been divided into several segments as follows:

1. The upper 110 mbsf (0-2.4 Ma) contains numerous biostratigraphic and magnetostratigraphic events, resulting in a wellconstrained segment that gives an estimated sedimentation rate of $45 \mathrm{~m} / \mathrm{m} . \mathrm{y}$.

2. The interval 110 to 135 mbsf (2.4-21.0 Ma) contains few stratigraphic events to constrain the sedimentation-rate curve. The presence of Discoaster quinqueramus from 116.5 to 118.0 mbsf and that of $S$. delmontensis from 116.5 to 135.4 mbsf suggest the occurrence of a hiatus (having a duration of about 11 $\mathrm{Ma})$ at a depth of about 116.5 mbsf.

3. The interval 135 to 224 mbsf (21.0-34.6 Ma) contains few stratigraphic events, and the sedimentation-rate curve is constrained by the placement of the occurrence of Reticulofenestra umbilica (Table 3, Fig. 9). Thus, this segment of the curve is extremely tenuous and has a minimum rate of $10 \mathrm{~m} / \mathrm{m} . \mathrm{y}$. and a maximum rate of $18 \mathrm{~m} / \mathrm{m} . \mathrm{y}$.

4. The interval 224 to 490 mbsf (34.6-44 Ma) is minimally constrained by biostratigraphic and magnetostratigraphic data that suggest a sedimentation rate of $60 \mathrm{~m} / \mathrm{m}$.y. Constraining the sedimentation-rate curve by three magnetostratigraphic events suggests that several of the biostratigraphic events are younger at Site 647 than the age assigned to these events at Site 112 by Berggren et al. (1985). Sedimentation rates were not estimated for the lower part of Hole 647A because of limited stratigraphic data.

\section{CONCLUSIONS}

The magnetostratigraphic and biostratigraphic results during Leg 105 vary from site to site. Although a paucity of microfos- 


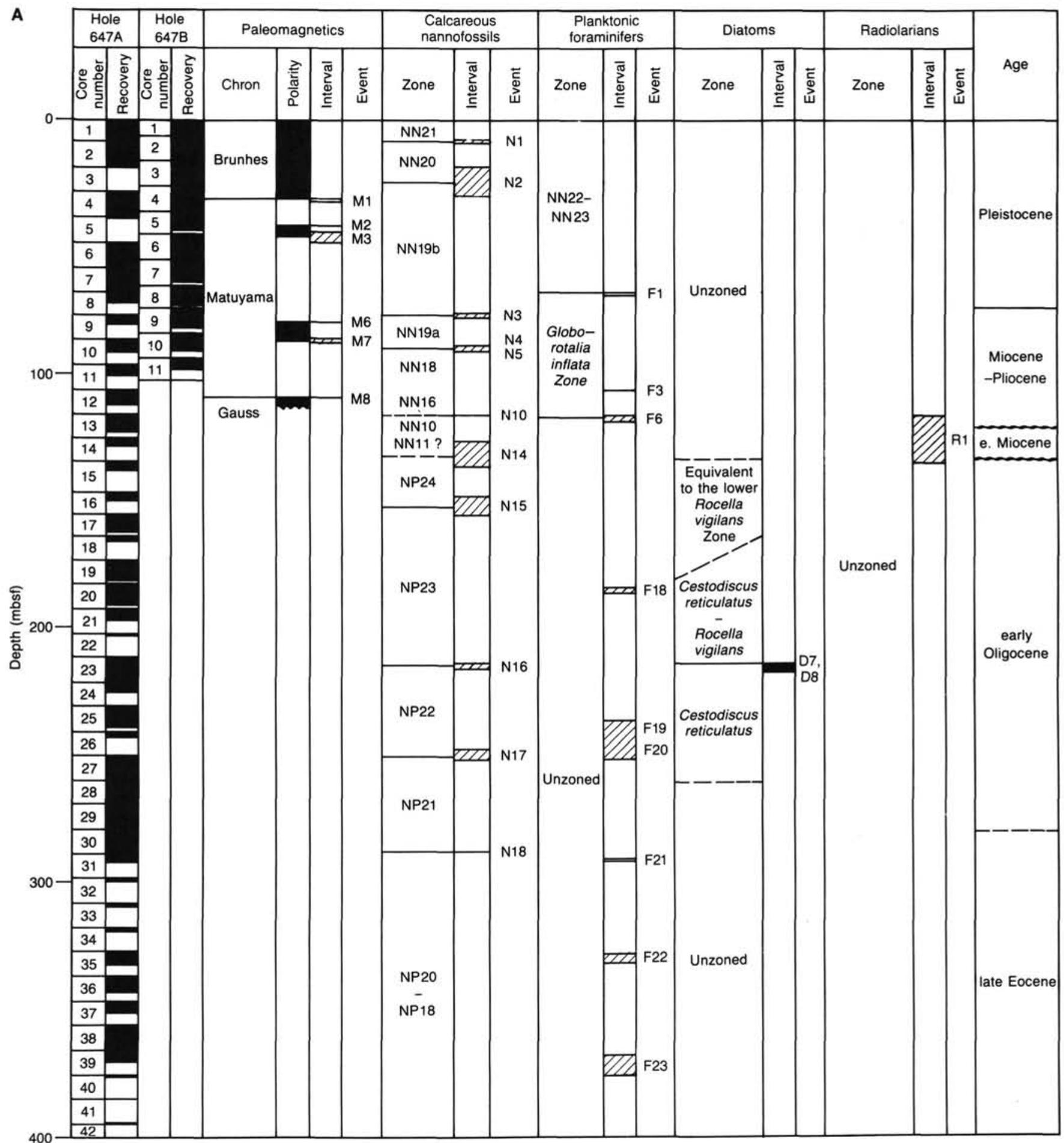

Figure 6. Correlation of coring results at Site 647 (Holes 647A and 647B) with magnetostratigraphy and biostratigraphy of calcareous nannofossils, planktonic foraminifers, and diatoms. Biostratigraphic events are indicated; the hatched area shows the depth ranges of the stratigraphic events. For an explanation of the event numbers, see Table 3 . Core recovery and normal polarity intervals shown in black.

sils and the magnetostratigraphy at Site 645 limit the overall stratigraphic resolution, the recovered sequence is early Miocene to Holocene in age.

The stratigraphic resolution is better defined at Site 646 with most microfossil groups and a magnetostratigraphy present. The stratigraphic results indicate that, with the possible exception of a hiatus between 672 and $682 \mathrm{mbsf}$, the sequence recovered at
Site 646 is continuous and has a late Miocene $(<9 \mathrm{Ma})$ to Holocene age. Based on the sedimentation-rate curve, the Pliocene/ Pleistocene boundary approximates $126 \mathrm{mbsf}$ and the Miocene/ Pliocene boundary approximates 470 mbsf.

Lower Eocene through lower Miocene, upper Miocene, and upper Pliocene through Holocene sediments were recovered from Site 647 . The upper 110 mbsf contains a reliable stratigraphy 


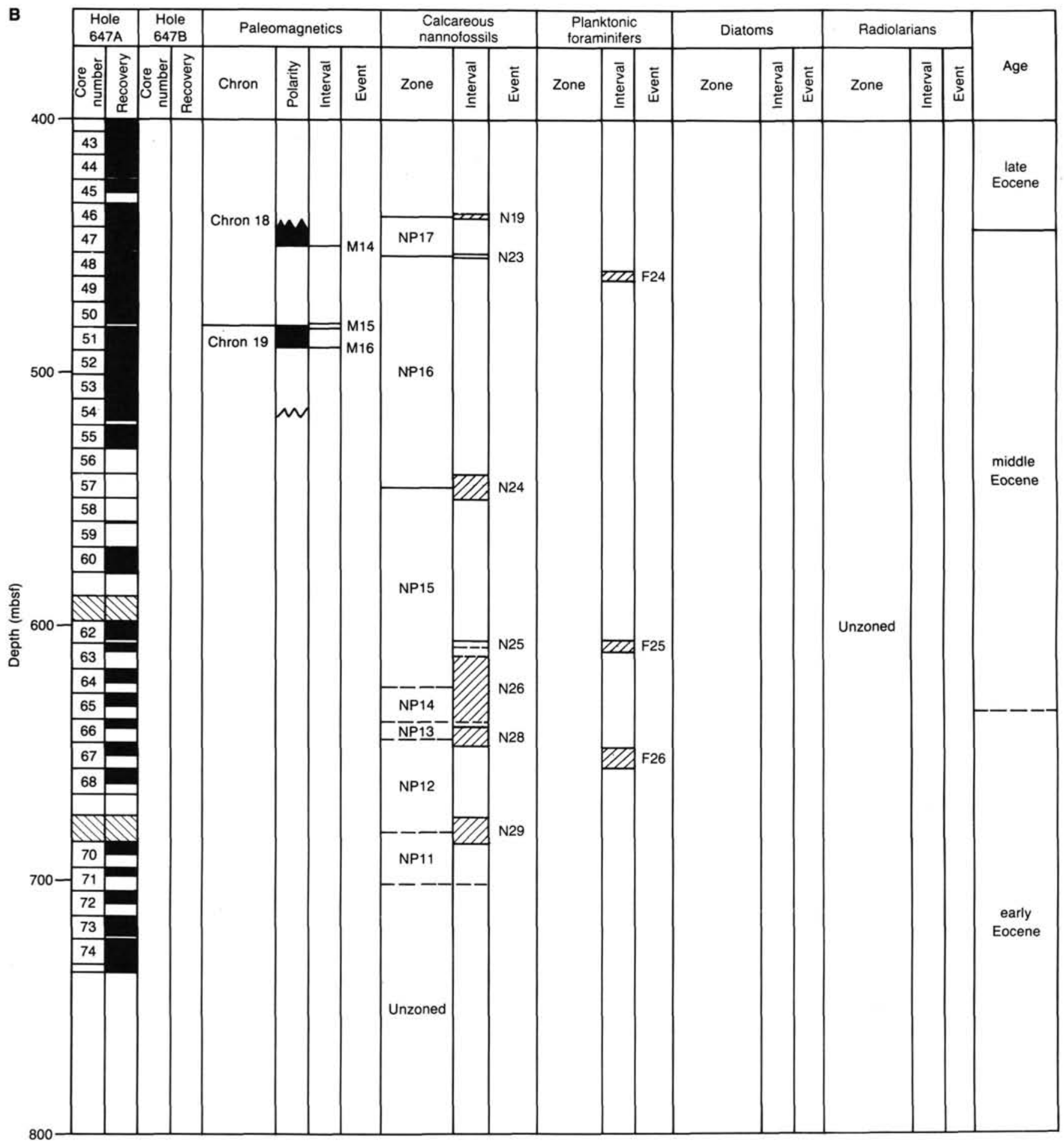

Figure 6 (continued).

constrained by a well-preserved calcareous microfossil assemblage and a magentostratigraphy. This interval is late Pliocene to Holocene in age. Based on the sedimentation-rate curve, the Pliocene/Pleistocene boundary approximates $80 \mathrm{mbsf}$.

Both the uppermost and lower Miocene are present at Site 647 , with the remaining portion of the Miocene represented by a hiatus having a duration of about $11 \mathrm{Ma}$. Because of stratigraphic uncertainties, the Miocene/Pliocene and the Oligocene/ Miocene boundaries cannot be placed accurately.
The Eocene-Oligocene sequence recovered from Site 647 is nearly continuous, with calcareous microfossils present throughout and siliceous microfossils present in the Oligocene sediments. Based on the sedimentation-rate curve, the Eocene/Oligocene boundary approximates $276 \mathrm{mbsf}$. The base of Hole $647 \mathrm{~A}$ is early Eocene in age, based on the calcareous nannofossil stratigraphy. This age agrees well with the estimated age of basement at this site (Chronozone C24), as determined by marine magnetic anomaly studies. 

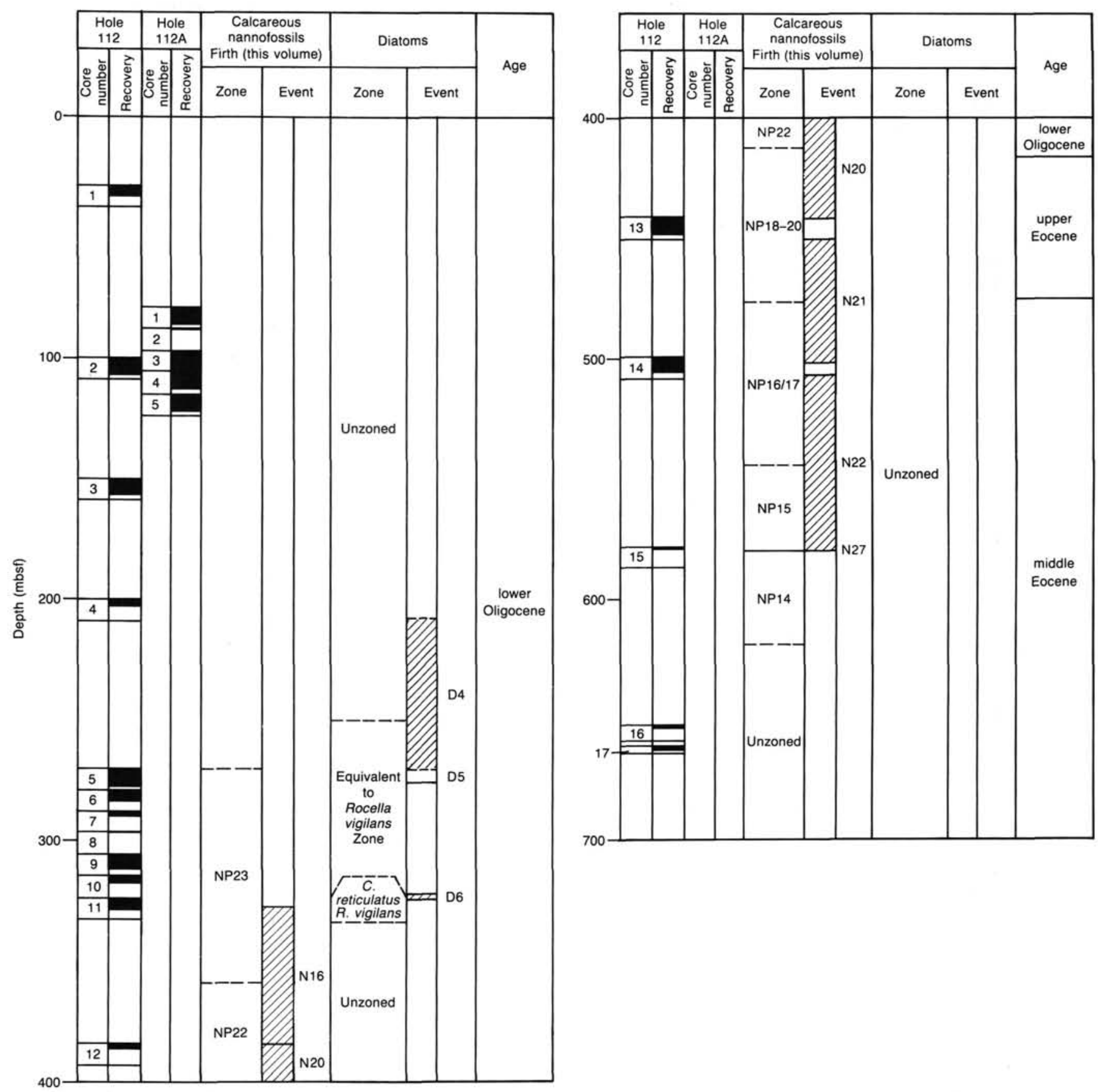

Figure 7. Correlation of coring results at Site 112 (Holes 112 and 112A) with biostratigraphy of calcareous nannofossils and diatoms. Biostratigraphic events are indicated; the hatched area shows the depth ranges of the stratigraphic events. For an explanation of the event numbers, see Table 4. Core recovery and normal polarity intervals shown in black. 


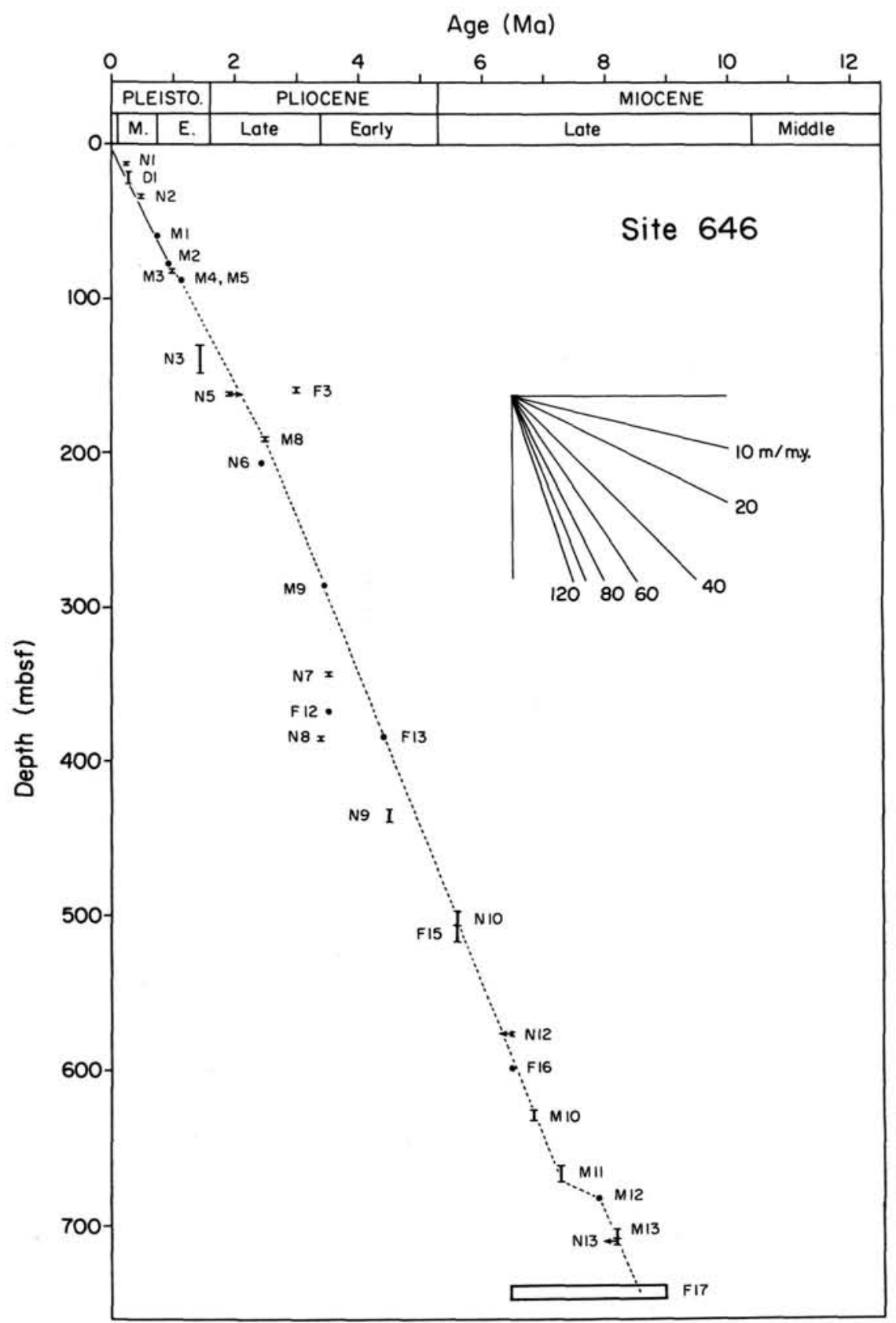

Figure 8. Sedimentation-rate curve for Site 646 , based on both paleomagnetic and biostratigraphic data. 


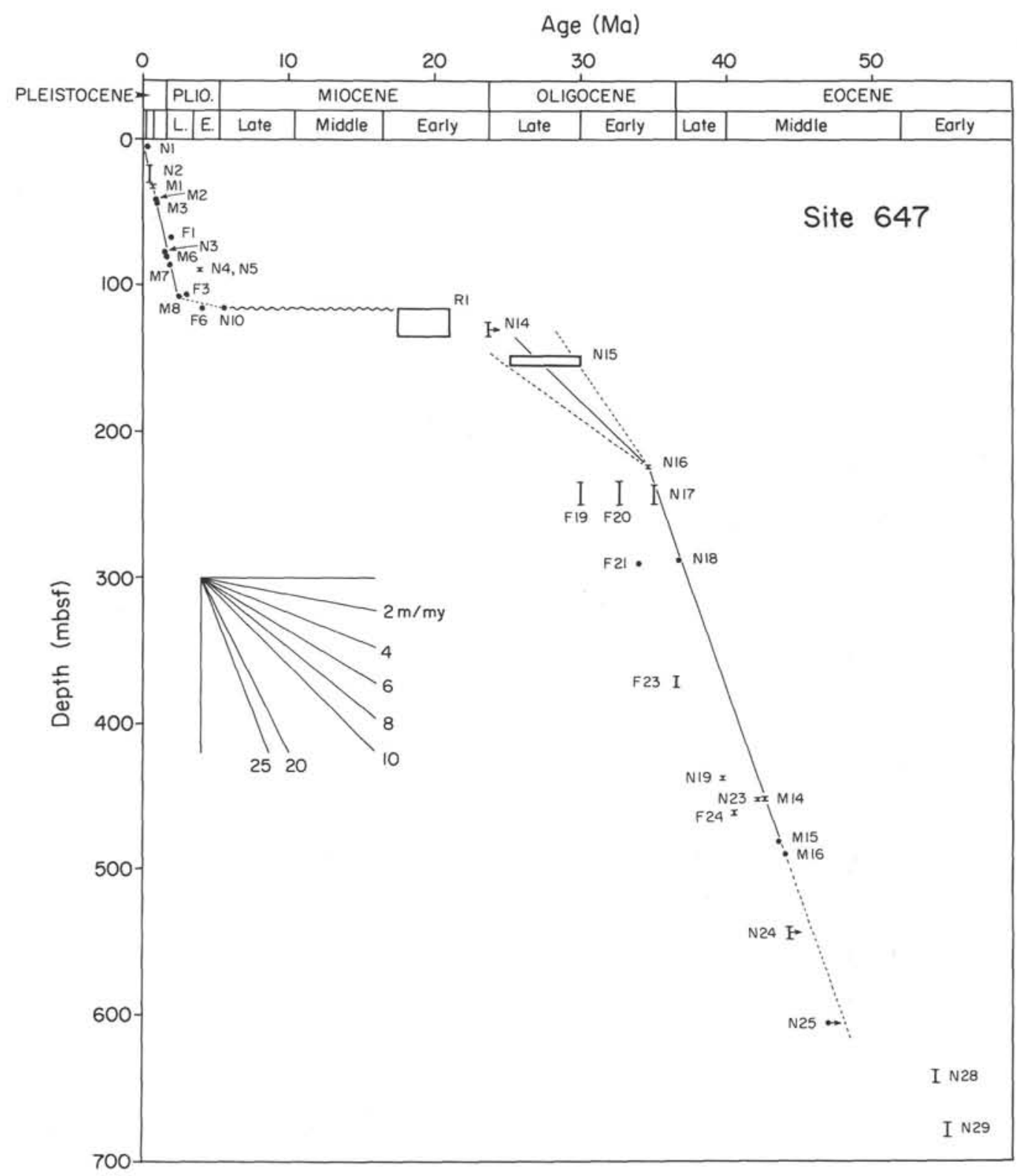

Figure 9. Sedimentation-rate curve for Site 647 , based on both paleomagnetic and biostratigraphic data. 


\section{REFERENCES}

Aksu, A. E., and Mudie, P. J., 1985. Magnetostratigraphy and palynology demonstrate at least 4 million years of Arctic sedimentation. Nature, 318:280-283.

Baldauf, J. G., 1984. Cenozoic diatom biostratigraphy and paleoceanography of the Rockall Plateau region, North Atlantic, Deep Sea Drilling Project Leg 81. In Roberts, D. G., Schnitker, D., et al., Init. Repts. DSDP, 81: Washington (U.S. Govt. Printing Office), 439478.

1985. A high resolution late Miocene-Pliocene diatom biostratigraphy for the eastern equatorial Pacific. In Mayer, L., Theyer, F., Thomas, E., et al., Init. Repts. DSDP, 85: Washington (U.S. Govt. Printing Office), 457-476.

1987. Diatom Biostratigraphy of the middle and high latitudes North Atlantic Ocean, Deep Sea Drilling Project Leg 94. In Ruddiman, W. F., Kidd., R. B., and Thomas, E., et al., Init. Repts. DSDP, 94: Washington (U.S. Govt. Printing Office), 729-762.

Baldauf, J. G., Thomas, E., Clement, B., Takayama, T., Weaver, P.P.E., Backman, J., Jenkins, G., Mudie, P, J., and Westberg-Smith, M. J., 1987. Magnetostratigraphic and biostratigraphic synthesis, Deep Sea Drilling Project Leg 94. In Ruddiman, W. F., Kidd, R. B., Thomas, E., et al., Init. Repts. DSDP, 94: Washington (U.S. Govt. Printing Office), 1159-1206.

Barron, J. A., 1980. Lower Miocene to Quaternary diatom biostratigraphy of Leg 57, off Northeastern Japan, DSDP. In Langseth, M., Okada, H., et al., Init. Repts. DSDP, 56, 57 (Pt. 2): Washington (U.S. Govt. Printing Office), 641-685.

Barron, J. A., 1985. Miocene to Holocene planktonic diatoms. In Bolli, M., Saunders, J. B., and Perch-Nielsen K. (Eds.), Plankton Stratigraphy: Cambridge (Cambridge Univ. Press), 763-809.

Bé, A.W.H., and Tolderlund, D. S., 1971. Distribution and ecology of living planktonic foraminifera in surface waters of the Atlantic and Indian Oceans. In Funnell, B. M., and Riedel, W. R. (Eds.), The Micropaleontology of the Oceans: Cambridge (Cambridge Univ. Press), 105-149.

Benedeck, P. M., and Müller, C., 1974. Nannoplankton-Phytoplankton-Korrelation im Mittel- und Ober-Oligozdn von NW-Deutschland. N. Jahrb. Geol. Paleontol. Monatsh., 385-397.

Berggren, W. A., 1972. Cenozoic biostratigraphy and paleobiogeography of the North Atlantic. In Laughton, A. S., Berggren W. A., et al., Init. Repts. DSDP, 12: Washington (U.S. Govt. Printing Office), $965-1002$.

1977. Late Neogene planktonic foraminiferal biostratigraphy of the Rio Grande Rise (South Atlantic). Mar. Micropaleontol., 2: 265-313.

Berggren, W. A., Aubry, M. P., and Hamilton, P., 1983. Neogene magnetobiostratigraphy of Deep Sea Drilling Project Site 516 (Rio Grande Rise, South Atlantic). In Barker, P. F., Johnson, D. J., Carlson, R. J., et al., Init. Repts. DSDP, 72: Washington (U.S. Govt. Printing Office), 675-714.

Berggren, W. A., Kent, D. V., and Van Couvering, J. A., 1985a. Neogene geochronology and chronostratigraphy. In Snelling, N.J. (Ed.), Geochronology and the Geologic Time Scale. Geol. Soc. (London) Mem., 10:211-250.

Berggren, W. A., Kent, D. V., and Flynn, J. J., 1985b. Paleogene geochronology and chronostratigraphy. In Snelling, N. J. (Ed.), The Chronology of the Geological Record. Geol. Soc. (London) Mem., 10:141-195.

Berggren, W. A., and Schnitker, D., 1983. Cenozoic marine environments in the North Atlantic and Norwegian-Greenland Sea. In Bott, M. H., Saxov, S., Talwani, M., and Thiede, J. (Eds.), Structure and Development of the Greenland-Scotland Ridge. NATO Conf. Ser. IV: $495-548$.

Bjorkland, K. R., 1976. Radiolaria from the Norwegian Sea, Leg 38 of the Deep Sea Drilling Project. In Talwani, M., Udintsev, G., et al., Init. Repts. DSDP, 38: Washington (U.S. Govt. Printing Office), 1101-1168.

Bjorkland, K. R., and Goll, R., 1989. In Eldholm, O., Thiede, J., et al., Proc. ODP, Sci. Results, 104: College Station, TX (Ocean Drilling Program).

Bujak, J. P., 1979. Proposed evolution of the dinoflagellates Rhombodnium and Gochtodinium. Micropaleontology, 25:308-324.
1984. Cenozoic dinoflagellate cysts and acritarchs from the Bering Sea and northern Pacific, DSDP Leg 19. Micropaleontology, 30:180-212.

Bukry, D., 1972. Further comments on coccolith stratigraphy, Leg 12, Deep Sea Drilling Project. In Laughton, A. S., Berggren, W. A., et al., Init. Repts. DSDP, 12: Washington (U.S. Govt. Printing Office), 1071-1083.

Chateauneuf, J.-J., and Gruas-Cavagnetto, C., 1978. Les zones de Wetzeliellaceae (Dinophyceae) du Bassin de Paris. Bull. Bureau Recherches Géol. Minières Ser., 2(4): 59-93.

de Vernal, A., 1986. Analyses palynologiques et isotopiques de sediments de la baie de Baffin et de la mer du Labrador: Elements d'une climatostratigraphie de Pleistocène superieur dans l'est du Canada [Ph.D. dissert.]. Université de Montréal.

Dzinordize, R. N., Jouse, A. P., Koroleva-Golikova, G. S., Kozlova, G. E., Nagaeva, G. S., Petrushevskaya, M. G., and Strelnikova, N. I., 1978. Diatom and radiolarian Cenozoic stratigraphy, Norwegian Basin, DSDP Leg 38. In Talwani, M., Udintsev, G., et al., Init. Repts. DSDP, 38-41: Washington (U.S. Govt. Printing Office), 289427.

Edwards, L. E., 1984. Miocene dinocysts from Deep Sea Drilling Project Leg 81, Rockall Plateau, eastern North Atlantic Ocean. In Roberts, D. G., Schnitker, D., et al., Init. Repts. DSDP, 81: Washington (U.S. Govt. Printing Office), 581-594.

Eldhom, O., Thiede, J., et al., 1987. Proc. ODP, Init. Repts., 104: College Station, TX (Ocean Drilling Program).

Fenner, J., 1984. Eocene-Oligocene planktonic diatom stratigraphy in the low-latitudes and high southern latitudes. Micropaleontology, $30: 319-342$.

Goll, R. M., 1978. Five Trissocyclid radiolaria from Site 338. In Talwani, M., Udintsev, F., et al., Init. Repts. DSDP, 38-41: Washington (U.S. Govt. Printing Office), 177-191.

Gombos, A. M., Jr., 1982. Early and middle Eocene diatom evolutionary events. Bacillaria, 5:225-242.

Gradstein, F. M., and Agterberg, F. P., 1982. Models of Cenozoic foraminiferal stratigraphy-northwestern Atlantic Margin. In Cubitt, J. M., and Reymant, R. A. (Eds.), Quantitative Stratigraphic Correlation: New York (John Wiley \& Sons), 119-170.

Gradstein, F. M., Kaminski, M. A., and Berggren, W. A., (1988). Cenozoic foraminiferal biostratigraphy, Central North Sea. Proc. 2nd Int. Workshop on Agglutinated Foraminifera, Vienna, June 23-28, 1986, 97-108.

King, C., 1983. Cainozoic micropaleontological biostratigraphy of the North Sea. Inst. Geol. Sci. Rept., 82/7:1-40.

Koizumi, I., 1973. The late Cenozoic diatoms of Sites 183-193, Leg 19, Deep Sea Drilling Project. In Creager, J. S., Scholl, D. W., et al., Init. Repts. DSDP, 19: Washington (U.S. Govt. Printing), 805-856.

Laughton, A. S., Berggren, W. A., et al., 1972. Init. Repts. DSDP, 12: Washington (U.S. Govt. Printing Office).

Martini, E., 1971. Standard Tertiary and Quaternary calcareous nannoplankton zonation. In Farinacci, A. (Ed.), Proc. 2nd Planktonic Conf. (Vol. 2): Rome (Edizioni Tecnoscienza), 739-777.

Martini, E., and Müller, C., 1976. Eocene to Pleistocene silicoflagellates from the Norwegian-Greenland Sea (DSDP Leg 38). In Talwani, M., Udintsev, G., et al., Init. Repts. DSDP, 38: Washington (U.S. Govt. Printing Office), 857-895.

Miller, K. G., Audrey, M.-P., Khan, M. J., Melillo, A. J., Kent, D. V., and Berggren, W. A., 1985. Oligocene to Miocene biostratigraphy, magnetostratigraphy, and isotopic stratigraphy of the western North Atlantic. Geology, 13:257-261.

Mudie, P. J., 1986. Palynology and dinoflagellate biostratigraphy of Deep Sea Drilling Project Leg 94, Sites 607 and 611, North Atlantic Ocean. In Ruddiman, W. F., Kidd, R. B., Thomas, E., et al., Init. Repts. DSDP, 94: Washington (U.S. Govt. Printing Office), 785812 .

1989. Palynology and dinocyst biostratigraphy of the late Miocene to Pleistocene, Norwegian Sea, ODP Leg 104, Sites 642 to 644. In Eldholm, O., Thiede, J., et al., Proc. ODP, Sci. Results, 104: College Station, TX (Ocean Drilling Program).

Müller, C., 1976. Tertiary and Quaternary calcareous nannoplankton in the Norwegian-Greenland Sea, DSDP Leg 38. In Talwani, M., Udintsev, G., et al., Init. Repts. DSDP, 38: Washington (U.S. Govt. Printing Office), 823-856. 
Murray, J. W., 1987. Bolboforma from North Atlantic sites, Deep Sea Drilling Project Leg 94. In Ruddiman, W. F., Kidd, R. B., Thomas, E., et al., Init. Repts. DSDP, 94: Washington (U.S. Govt. Printing Office), 813-814.

Okada, H., and Bukry, D., 1980. Supplementary modification and introduction of code numbers to the low-latitude coccolith-biostratigraphic zonations (Bukry, 1973, 1975). Mar. Micropaleontol., 5: 321-325.

Olszewska, B., and Smagowicz, M., 1977. Porownanie podzialow biostratygraficznych gornej kredy i paleogenu jednostki dukielskiej na podstawie otwornic planktonicznych i nannoplanktonu wapiennego. Przeglad Geol., 7:359-363.

Reidel, W. R., and Sanfilippo, A., 1978. Stratigraphy and evolution of tropical Cenozoic radiolarians. Micropaleontology, 23:61-96.

Roberts, D., Schnitker, D., et al., 1984. Init. Repts. DSDP, 81: Washington (U.S. Govt. Printing Office).

Ruddiman, W. R., Kidd, R., Thomas, E., et al., 1987. Init. Repts. DSDP, 94: Washington (U.S. Govt. Printing Office).
Schrader, H.-J., and Fenner, J., 1976. Part 1. Norwegian Sea Cenozoic diatom biostratigraphy. In Talwani, M., Udintsev, G., et al., Init. Repts. DSDP, 38: Washington (U.S. Govt. Printing Office), 921962.

Srivastava, S. P., Arthur, M., et al., 1987. Proc. ODP, Init. Repts., 105: College Station, TX (Ocean Drilling Program).

Verdenius, J. G., and Van Hinte, J. E., 1983. Central Norwegian-Greenland Sea: Tertiary arenaceous foraminifera, biostratigraphy and environment. Proc. 1st Workshop Arenaceous Foraminifera, Sept. 79, 1981. Continental Shelf Inst. Publ., 108:173-224.

Weaver, P.P.E., and Clement, B. M., 1986. Synchroneity of Pliocene planktonic foraminiferal datums in the North Atlantic. Mar. Micropaleontol., 10:295-307.

Date of initial receipt: 10 June 1988

Date of acceptance: 29 September 1988

Ms 105B-165

Table 4. Site 112 biostratigraphic events.

\begin{tabular}{|c|c|c|}
\hline Event & $\begin{array}{c}\text { Sample } \\
\text { interval }(\mathrm{cm})\end{array}$ & $\begin{array}{l}\text { Depth } \\
\text { (mbsf) }\end{array}$ \\
\hline \multicolumn{3}{|l|}{ Calcareous nannofossils } \\
\hline N6 LO Reticulofenestra umbilica & $11 R-4,69-73-12 R-1,44-48$ & $327.70-384.46$ \\
\hline $\begin{array}{l}\text { N20 LO Discoaster barbadiensis } \\
\text { and D. saipanensis }\end{array}$ & $12 \mathrm{R}-1,44-48-13 \mathrm{R}-1,120-124$ & $384.46-442.20$ \\
\hline N21 FO Chiasmolithus oamaruensis & $13 R-5,120-124-14 R-2,118-120$ & $448.24-501.19$ \\
\hline $\begin{array}{l}\text { N22 LO Chiasmolithus solitus and } \\
\text { FO } R \text {. bisecta }\end{array}$ & $14 \mathrm{R}-5,103-107-15 \mathrm{R}-1,6-10$ & $506.07-578.48$ \\
\hline N27 LO Rhabdosphaera inflata & $15 \mathrm{R}-1,6-10-15 \mathrm{R}-1,47-48$ & $578.48-578.85$ \\
\hline \multicolumn{3}{|l|}{ Diatoms } \\
\hline D4 Occ. Rocella vigilans & $5 R-4,95-99$ & 275.47 \\
\hline $\begin{array}{l}\text { D5 Occ. Melosira architecuralis, } \\
\text { Rocella praenitidus, and Go- } \\
\text { niothecium decoratum }\end{array}$ & $5 R-1,85-89-9 R-5,94-98$ & $270.87-311.96$ \\
\hline $\begin{array}{l}\text { D6 Occ. Asterolampra schmidtii } \\
\text { and Synedra jouseana }\end{array}$ & $11 \mathrm{R}-1,108-112-11 \mathrm{R}-2,108-112$ & $325.10-326.60$ \\
\hline
\end{tabular}

